\title{
Nefret Saikinin Türk Ceza Kanunu’nda Yer Alan Ayırımcılık Suçuna Etkisi
}

\author{
The Effect of the Hate Motivation on the Discrimination Crime in the \\ Turkish Penal Code
}

\author{
Recep Kahraman ${ }^{*}$ iD
}

\section{öz}

Nefret ve ayırımcılık suçu, hürriyete karşı işlenen suçlardandır. Dil, ırk, milliyet, renk, cinsiyet, engellilik, siyasi düşünce, felsefi inanç, din veya mezhep farklılığından kaynaklanan nefret saikiyle, ceza normunda yer alan seçimlik hareketlerden birinin gerçekleştirilmesi durumunda nefret ve ayırımcılık suçu işlenmektedir. 6529 sayılı Kanun değişikliğiyle birlikte nefret kavramı, ayırımcılık suçunun hem başlığına hem de metin kısmına eklenerek, hem suçun adı hem de suçun manevi unsuru değiştirilmiştir. Değişiklikle birlikte nefret kavramının hukuksal, sosyolojik ve kriminolojik sonuçları ortaya çıkmaktadır. Nefret kavramı, ayırımcılık suçunun yapısı, hukuki niteliği, nefret saikine ilişkin modeli ve suçla korunan hukuki yararı etkilemektedir. Nefret saiki suçun unsuru olarak düzenlendiğinden, nefret saikiyle hareket edildiğinin kanıtlanması gerekmektedir. Karmaşık bir duygu olan nefret saikinin kanıtlanabilmesinin zorluğuna bağlı olarak, nefret ve ayırımcılık suçunun ispatlanması oldukça zor olmaktadır.

Anahtar Kelimeler: Nefret Suçu, Nefret Söylemi, Ayırımcılık Suçu, Nefret Saiki, Ön Yargı Saiki

\section{ABSTRACT}

The hate and discrimination crime is among the crimes against liberty. The hate and discrimination crime is committed when one of the optional actions included in the penal norm is carried out with the motive of hate arising from differences in language, race, nationality, color, gender, disability, political opinion, philosophical belief, religion or religious sect. With the amendment of code numbered 6529 , hate has been added to both the title and the text of the discrimination crime. Both the name of the crime and the moral element of the crime have been changed. With the change, legal, sociological and criminological consequences of the hate emerge. The hate affects the structure of the discrimination crime, its legal nature, the model of hate motivation and the legal benefit protected by the crime. Since the hate motivation is regulated as an element of the crime, it must be proved that it is motivated by hate. Due to the difficulty of proving the hate motivation, which is a complex emotion, it is very difficult to prove hate and discrimination crime.

Keywords: Hate Crime, Hate Speech, Discrimination Crime, Hate Motivation, Bias Motivation

* Dr. Öğretim Üyesi, Necmettin Erbakan Üniversitesi Siyasal Bilgiler Fakültesi, Maliye Bölümü

Sorumlu Yazar/Correspondence Author: Recep Kahraman

E-posta/E-mail: rkahraman@erbakan.edu.tr

Geliş Tarihi/Received: $\quad 16.02 .2021$

Kabul Tarihi/Accepted:

28.05.2021 


\section{GíRiş}

5237 sayılı Türk Ceza Kanunu'nun 122'nci maddesinde düzenlenmiş olan ayırımcılık suçunda, 6529 sayılı Kanun'la birlikte kapsamlı değişiklikler yapılmıştır. Nefret kavramı suçun başlığına eklenerek, suçun adı nefret ve ayırımcılık olarak değiştirilmiştir. Ayrıca nefret saiki suçun manevi unsuruna eklenerek, normda yer alan hareketlerin nefret saikiyle gerçekleştirilmesi yaptırıma bağlanmıştır.

Doktrinde ve yargı kararlarında nefret, nefret suçu, nefret söylemi, nefret ve ayırımcılık suçu ile ilgili çalışmalar yeteri kadar işlenmiş olmasına rağmen nefret saikinin ayırımcılık suçuna etkisi ayrıca çalışılmamıştır. Bu nedenle kavrama ve uygulanmasına ilişkin farklı değerlendirmeler yapılmaktadır. Çalışmanın amacı, nefret saikinin, ayırımcılık suçundaki etkisini ortaya koymak ve somut olayda tespitine yönelik inceleme metoduna katkı sağlamaktır. İnsan hakları hukukunun bir konusu olarak kabul edilen ayırımcılık yasağında, nefret saikini uygulanabilirlik açısından değerlendirmektir. Amacı gerçekleştirebilmek için doktrinden, ulusal ve uluslararası yargı kararlarından yararlanılmıştır. Çalışmada bir suç tipi analizi yapılmamıştır. Çalışmanın amacı, nefret saikinin ayırımcılık suçuna etkisini tüm yönleriyle ortaya koymaktır. Bu nedenle çalışmada, nefret ve ayırımcılık suçunun maddi unsurlarına ilişkin bir değerlendirmeye yer verilmemiştir.

\section{KAVRAM VE TANIM}

5237 sayılı Kanun'un 122'nci maddesinde düzenlenmiş olan nefret ve ayırımcılık suçunun anlaşılabilmesi adına nefret saiki ve ön yargı saiki kavramlarının; nefret suçu, ayırımcılık suçu ve ön yargı suçlarının tanımlarının ve birbirleriyle bağlantılarının öncelikli olarak açıklanması gerekmektedir.

Nefret saiki, bir kişiye ya da gruba yönelik bir tür ön yargı olup karşı tarafın kötü, huzursuz, mutsuz olmasını isteme duygusudur. ${ }^{1}$ Ön yargı saiki, belirli somut bir durumla ilgili önceden edinilmiş olan olumlu veya olumsuz yargı olarak ifade edilebilmektedir. ${ }^{2}$ Ön yargının kaynağı bir kişi veya topluluk; kişi veya topluluğun özellikleri ya da kişi veya topluluğun sahip olduğu düşünce olabilmektedir. ${ }^{3}$ Ön yargının varlığına bağlı olarak kişinin iradesi nesnel olmayıp özneldir. ${ }^{4}$ Nefret saiki aynı zamanda ön yargı saiki iken her ön yargı saiki, nefret saiki olarak nitelendirilmemelidir. Ön yargı saikini oluşturan duygu, nefret saikine nazaran daha kapsamlı olup, bir kişi ya da gruba takınılmış olan tavır, karşı tarafın mutsuz olmasını isteme duygusunu da kapsayabilecek şekilde geniş düşünülmelidir. Örneğin karşı tarafın farklı bir dine mensup olmasından dolayı, kişiyle arasına mesafe konulması ön yargı saikini oluşturmaktayken, nefret saikini içermemektedir. Oysa farklı dine mensup kişinin,

1 SCHIEMANN, Anja, "Änderungen im Strafgesetzbuch durch das Gesetz zur Bekämpfung des Rechtsextremismus und der Hasskriminalität”, KriPoZ, 2020/5, s. 270.

2 SERAFIN, Maja Anna, Hate Crimes: Auf der Suche nach einer adäquaten Reaktion des Strafrechts, Schriftenreihe des Max-Planck-Instituts, Freiburg im Breisgau, 2019, s. 13.

3 DANNER, Allison Marston. "Bias Crimes and Crimes Against Humanity: Culpability in Context”, Buffalo Law Review, 2002, Vol. 6, Iss. 1, s. 410.

4 COESTER, Marc, "Das Konzept der Vorurteilskriminalität”, Wissenschaft Demokratie Schriftenreihe des Instituts für Demokratie und Zivilgesellschaft, IDZ, 2018/4, s. 42. 
kötü, huzursuz, mutsuz olmasını isteme duygusuna sahip olma, hem ön yargı hem de nefret saikini içermektedir. ${ }^{5}$

Nefret suçu, bir kişi ya da gruba karşı belli bir topluluğa mensup olmaktan, bir aidiyet olgusundan kaynaklanan ön yargı saiki ile işlenen ve genellikle şiddet içeren suç tipi olarak tanımlanabilmektedir. ${ }^{6}$ Türk hukuk sisteminde nefret suçlarına yönelik özel bir düzenleme bulunmamakla birlikte 5237 sayılı Kanun'un 122 'nci maddesinde yer alan nefret ve ayırımcilık suçuyla birlikte, 115 'inci maddesinde yer alan inanç, düşünce ve kanaat hürriyetinin kullanılmasını engelleme suçu, 125'inci maddesinde yer alan hakaret suçu, 153'üncü maddesinde yer alan ibadethanelere ve mezarlıklara zarar verme suçu ve 216'ncı maddesinde yer alan halkı kin ve düşmanlığa tahrik ve aşağılama suçu da nefret suçu olarak kabul edilebilmektedir. ${ }^{7}$

Irk, etnik köken, cinsiyet, din vb. birtakım sebeplerden kaynaklı olarak bir gruba ya da grubun üyelerine karşı, ceza kanunuyla yasaklanmış olan dışlayıcı davranışların gerçekleştirilmesi, ayırımcılık suçu olarak ifade edilebilmektedir. ${ }^{8}$

Ceza kanununda yer alan bazı suç tiplerinde fail, mağdurdan kaynaklanan ön yargı ile suç işlemektedir. Bu suç tiplerine ön yargı suçları denilmektedir. ${ }^{9}$ Ön yargı suçları, nefret suçunu ve ayırımcllık suçunu kapsayan bir geniş bir anlama sahiptir. ${ }^{10}$ Ön yargı, davranışa dönüştüğünde ayırımclık ortaya çıkmaktadır. ${ }^{11}$ Örneğin 5237 sayılı Kanun'un 122'nci maddesinde yer alan fiil, failin duyduğu nefret şeklindeki ön yargı ile işlenmektedir. ${ }^{12}$ Nefret ve ayırımcllık suçunda kişiye

5 DANCYGİER, Rafaela M./GREEN, Donald P. "Hate Crime", Prejudice, Stereotyping and Discrimination, (Edited by John Dividio, Miles Hewstone, Peter Glick And Victoria Esses), SAGE, 2011, California, s. 294.

6 SCOTTING, Troy A. "Hate Crimes and the Need for Stronger Federal Legislation", Akron Law Review, 2001, Vol. 34, Iss. 4, s. 860; SULLAWAY, Megan, "Psychological Perspectives on Hate Crime Laws", Psychology, Public Policy, and Law, 2004, Vol. 10, Iss. 3, s. 250; JACOBS, James B./HENRY, Jessica S. “The Social Construction of a Hate Crime Epidemic”, The Journal of Criminal Law \& Criminology, Northwestern University, 1996, Vol. 86. Iss. 2, s. 366; LAWRENCE, Frederick M. “The Punishment of Hate: Towards a Normative Theory of Bias-Motivated Crimes", Michigan Law Review, 1994, Vol. 93, Iss. 2, s. 354; COESTER, s. 43; BENIER, Kathryn, “The Harms of Hate”, International Review of Victimology, 2017, Vol. 23, Iss. 2, s. 180; DANCYGİER/GREEN, s. 495; SOKULLU, Füsun Akınc1, “Hate Crimes”, Annales De La Facultede Droit d'Istanbul, 2009, Vol. 58, s. 102; ÖNER, Mehmet Zülfü, “İngiltere Hukukunda Nefret Suçları”, TBBD, 2015, Cilt: 27, Sayı: 116, s. 88; TÜRAY, Aras, "Nefret Suçları ve Türk Ceza Hukukundaki Güncel Gelişmeler”, CHD, 2014, Cilt: 9, Sayı: 26, s. 79; SINAR, Hasan, “Türk Hukukunda Nefret Suçlarına İlişkin Yasal Düzenleme Çalışmaları”, Prof. Dr. Nur Centel’e Armağan, MÜHFHAD, 2013, C: 19, S: 2, s. 1272.

7 DEMIRBAŞ, Timur, “Nefret Söylemi ve Nefret Suçları”, Prof. Dr. Şeref ERTAŞ’a Armağan, DEÜHFD, 2017, s. 2701.

8 KARAN, Ulaş, Uluslararası İnsan Hakları Hukuku ve Anayasa Hukuku Işığında Eşitlik İlkesi ve Ayırımcılık Yasağı, On İki Levha Yayınevi, İstanbul, 2017, s. 65; TÜRAY, Aras, Nefret Söylemi Bağlamında Halkı Kin ve Düşmanlığa Tahrik Suçu, Seçkin Yayınevi, Ankara, 2016, s. 22; TANERİ, Gökhan, Hürriyete Karşı Suçlar, Seçkin Yayınevi, Ankara, 2020, s. 667; ŞAHİNKAYA, Yalçın, Uluslararası İnsan Hakları Hukukunda Nefret Söylemi ve Karşılaştırmalı Nefret Suçları, Adalet Yayınevi, Ankara, 2016, s. 14; YURTCAN, Erdener Yargıtay Kararları Işı̆̆ında Hürriyete Karşı Suçlar, İstanbul Barosu Yayınları, İstanbul, 2014, s. 176; DENİZ, Buket, Engelli Hakları ve Ayrımcılık Yasağı, Seçkin Yayınevi, Ankara, 2020, s. 17.

9 HARE, Ivan, "Legislating Against Hate-The Legal Response to Bias Crimes", Oxford Journal of Legal Studies, 1997, Vol. 17, Iss. 3, s. 416.

10 SULLAWAY, s. 252.

11 DANCYGİER/GREEN, s. 294.

12 BAYRAKTAR, Köksal, "Nefret ve Ayırımcılık Suçu”, YÜHFD, 2017, Cilt: 13, Sayı: 1, s. 70. 
karşı, mensup olduğu gruba ait karakteristik özelliklerden kaynaklanan ön yargı, nefret saiki olarak somutlaştırılmaktadır. Failin ön yargısı olan nefret saiki, ayırımcılık suçunun sebebi olarak kabul edilmektedir. $^{13}$

\section{NEFRET VE AYIRIMCILIK SUÇU}

XX. yüzyılda siyaset adamları, düşünürler ve toplum bilimcilerin bireye bakış açısı yeni boyutlara yönelmiştir. Bu anlayışa göre, bireylerin eşitliği soyut olarak kalmamalı, somut hayatın içerisinde gerçekleşmeli; bireyler, hayatın her alanında herhangi bir ayırıma tabi tutulma kuşkusu duymadan yaşayabilmelidir. ${ }^{14}$ Farklı aidiyet duygularını barındıran toplum içinde, farklılığından dolayı kişilerin dışlanabilme ihtimaline karşı modern ceza kanunlarında ayırımcılık suçuna yer verilmelidir. ${ }^{15}$ Ayırımcılık suçunun ceza kanununda düzenlenmesi, yaşadığımız yüzyılda oluşan insana bakış açısının ceza normunda kendisine yer bulması olarak değerlendirilmeli ve yorumlanmalıdır. ${ }^{16}$

Türk hukukunda ayırımcılık suçu 765 sayılı Kanun'da yer almamaktadır. İlk defa 5237 sayılı Kanun'da düzenlenmiştir. Kanun yürürlüğe girdiğinde ayırımcılık başlığını taşıyan norma, 02.03.2014 tarih ve 6529 sayılı Kanun’la birlikte nefret kavramı eklenmiştir. Böylece "ayırımcılık” başlı̆̆ı, "nefret ve ayırımcılık" şeklinde değiştirilmiştir. ${ }^{17}$

Çalışmada öncelikle "ayırımcılık” kavramının terminolojik olarak değerlendirilmesi gerekmektedir. Türk Dil Kurumu sözlüğünde "ayrımcılık” ifadesi kullanılmaktadır. ${ }^{18}$ Ancak kanun koyucu, 5237 sayılı Kanun'un 122’nci maddesinde “ayırımcılık” kelimesini kullanmayı tercih etmiştir. Çalışmanın kapsamı, 122'nci maddede düzenlenmiş olan "nefret ve ayırımcilık suçu” olduğundan, yasal ifadeye

13 ERSOY, Uğur, "Nefret ve Ayrımcılık Suçu (TCK m. 122)", CHD, 2017, Cilt: 12, Sayı: 34, s. 11; Nefret saikinin kaynağı 5237 sayılı Kanun'un 122'nci maddesine göre mağdurun kişiliği ve diğer başka özellikleri olmayıp "dil, ırk, milliyet, renk, cinsiyet, engellilik, siyasi düşünce, felsefi inanç, din veya mezhep” farklılığıdır. Görüldügü gibi nefret ve ayırımcılık suçunda nefret saikinin kaynağı olarak on koruma grubu belirlenmiştir. Suçta ve cezada kanunilik ilkesi gereğince, normda sayılmayan bir gruptan kaynaklanan nefret sakiyle hareket edilmesi suç oluşturmamaktadır. KOCASAKAL, Ümit, “5237 Sayılı Türk Ceza Kanunu'nda Nefret ve Ayrımcılık Suçu (TCK m. 122)”, CHD, 2015, Cilt: 10, Sayı: 28 , s. 23.

14 BAYRAKTAR, s. 56.

15 ALEXANDER, Larry, "What Makes Wrongful Discrimination Wrong? Biases, Preferences, Stereotypes, and Proxies", University of Pennsylvania Law Review, 1992, Vol. 141, s. 157; KARAN, Uluslararası İnsan Hakları Hukuku ve Anayasa Hukuku Işı̆̆ında Eşitlik İlkesi ve Ayrımcılık Yasağı, s. 65; CANKURT, Ezgi, "Cinsel Yönelime İlişkin Yaşam Tarzına Müdahalenin TCK Bakımından Değerlendirilmesi”, BÜHFD, 2017, Cilt: 3, Sayı: 6, s. 112; SINAR, s. 1272; İNCEOĞLU, Asuman Aytekin, “Türk Ceza Kanunu’nun 122. Maddesinde Düzenlenen Nefret ve Ayrımcılık Suçunun Nefret Suçu Kavramı Çerçevesinde Değerlendirilmesi”, LHD, 2015, Cilt: 13, Sayı: 150, s. 51; ÖZTÜRK, Nurten, Nefret ve Ayrımcılık Suçu, Adalet Yayınevi, Ankara, 2017, s. 8; ÇİÇEK, Gökçe Serim, Türk Ceza Kanununda Nefret ve Ayrımcılık Suçu, Seçkin Yayınevi, Ankara, 2021, s. 35.

16 AĞIRBAŞLI, Şennur, Sınırlı Ayrımcılık Yasağından Genel Eşitlik İlkesine, Seçkin Yayınevi, Ankara, 2009 , s. 32.

17 HAFIZOĞULLARI, Zeki/ÖZEN, Muharrem, Kişilere Karşı Suçlar, Türk Ceza Hukuku Özel Hükümler, USA Yayınevi, Ankara, 2016, s. 224.

18 "Ayırımcılık" kelimesine Türkçe dilbilgisi kuralları açısından değerlendirilmesi için bkz. İki heceden oluşan bazı kelimelerde ilk hecede geniş (o, ö, a, e) ünlü; diğer hecede ise dar ünlü (u, ü, l, i) bulunduğunda ve bunlara ünlü harf ile başlayan bir ek getirildiğinde ikinci hecede yer alan dar ünlü harf düşer. Bu nedenle ay(1)rım kelimesindeki (1) harfinin düşerek ayrım şeklinde kullanılması gerekmektedir. TEKIN, T. “Türkçede Morfofonemik Değişmeler: Dar Ünlü Nöbetleşmesi”, DAD, 1995, 6, s. 105. 
sadık kalma düşüncesiyle çalışmanın başlığında ve içeriğinde "ayırım" ve "ayırımcılık" kelimeleri kullanılmıştır. ${ }^{19}$

Nefret ve ayırımcılık suçu, 5237 sayılı Türk Ceza Kanunu’nda Hürriyete Karşı Suçlar başlıklı yedinci bölümde 122'nci maddede düzenlenmiştir: "Dil, ırk, milliyet, renk, cinsiyet, engellilik, siyasi düşünce, felsefi inanç, din veya mezhep farkllhğından kaynaklanan nefret nedeniyle; a) Bir kişiye kamuya arz edilmiş olan bir taşınır veya taşınmaz malın satılmasını, devrini veya kiraya verilmesini, b) Bir kişsinin kamuya arz edilmiş belli bir hizmetten yararlanmasını, c) Bir kişinin işe alınmasını, d) Bir kişinin olağan bir ekonomik etkinlikte bulunmasını, engelleyen kimse bir yıldan üç yıla kadar hapis cezası ile cezalandirllir." 20

Dil, ırk, milliyet, renk, cinsiyet, engellilik, siyasi düşünce, felsefi inanç, din veya mezhep farklllığından kaynaklanan nefret saikiyle, normda yer alan hareketlerden birisi gerçekleştirildiği takdirde nefret ve ayırımcılık suçu işlenmiş olmaktadır. ${ }^{21}$

Nefret ve ayırımcllık suçu, eşitlik ilkesi çerçevesinde değerlendirilmelidir. Normda yer alan ayırımclık kabul edilen hareketler, haklar ve özgürlükler konusunda insanlar arasında eşit hareket edilmediğinin somutlaştırılmış halleridir. ${ }^{22}$ Tüm hak öznelerinin, insan haklarından eşit koşullarda

19 "Ayırımcılık" kelimesinin, terminolojik olarak hatalı kullanıldığına ilişkin eleştiriler için bkz. Türkçe dilbilgisi kuralları açısından "ayırım" ve "ayırımcılık" kelimelerinin kullanılması hatalı olup doğrusu "ayrım" ve "ayrımcılık"tır. Ancak Türkçe dilbilgisi kurallarına aykırı şekilde 5237 sayılı Kanun’un 122'nci maddesinde ve 1982 Anayasası̉nın 10'uncu ve 70'inci maddelerinde kavram hatalı olarak kullanılmaktadır. ERSOY, "Nefret ve Ayrımcılık Suçu (TCK m.122)", s. 10.

20 Nefret ve ayırımcllık suçu, seçimlik hareketli bir suçtur. Seçimlik hareketlerden ilki belirtilen sebeplerle ayırım yaparak kamuya arz edilmiş olan taşınır veya taşınmaz malın satılmasının, devrinin veya kiraya verilmesinin engellenmesidir. Diğer seçimlik hareket, kamuya arz edilmiş belli bir hizmetten yararlanmanın engellenmesidir. Üçüncü seçimlik hareket, kişinin işe alınmasının engellenmesidir. Son seçimlik hareket ise bir kişinin olağan bir ekonomik etkinlikte bulunmasının engellenmesidir. BAYRAKTAR, s. 74; Ayırımcllık yasağı, yapısı ve kapsamı gereği toplumsal yaşamın her alanında karşılaşllabilen bir olgu olmasına rağmen ceza normunda sınırlı bir düzenleme tercih edilmiştir. Uluslararası sözleşmelerde temel insan hakkı özelliğinden dolayı düzenlemenin ceza normu tipinde yer almaması beklenmemelidir. Ayırımclık filinin ceza normuna aktarılmasında ise ceza kanununun genel ilkeleri ve uygulamalarının dikkate alınması gerekirdi. Ceza normunda ayırımcılık hareketlerinin örnekleyici olarak sayılması, suçta ve cezada kanunilik ilkesi ile çelişmektedir. DÖNMEZ, Burcu Demren, "Ayrımcilık Suçu”, TBBD, 2012, S. 12, s. 13.

21 TANERİ, s. 655.

22 SERAFIN, s. 67; ÖZTÜRK, s. 95; AĞIRBAŞLI, s. 37; ÇİÇEK, s. 36; YAŞAR, Osman/GÖKCAN, Hasan Tahsin/ARTUÇ, Mustafa, Yorumlu ve Uygulamalı Türk Ceza Kanunu Cilt III, Adalet Yayınevi, Ankara, 2014, s. 4057; ŞEN, Ersan, "Yeni Türk Ceza Kanunu’nun 115. ve 122. Maddelerine İlişkin Bir değerlendirme”, İBD, 2005/2, Cilt: 79, s. 362; ERSOY, "Nefret ve Ayrımcilık Suçu (TCK m.122)", s. 13; BAYRAKTAR, s. 62; ÇALIŞKAN, Suat, Hürriyete Karşı Suçlar, Platon Hukuk Yayınevi, İstanbul, 2020, s. 186; MERAN, Necati, Kişilere Karşı Suçlar, Seçkin Yayınevi, Ankara, 2008. s. 557; KOCASAKAL, s. 11; MEMİ̧, Pınar, "Ayrımcılık Suçunun Özürlüler Bakımından Değerlendirilmesi", GÜHFD, 2009/2, s. 72; CANKURT, s. 112; ÖZBEK, Veli Özer/DOĞAN, Koray/BACAKSIZ, Pınar, Türk Ceza Hukuku Özel Hükümler, Seçkin Yayınevi, Ankara, 2020, s. 484; HAFIZOĞULLARI/ÖZEN, s. 224; İNCEOĞLU, Türk Ceza Kanunu’nun 122. Maddesinde Düzenlenen Nefret ve Ayrımcılık Suçunun "Nefret Suçu" Kavramı Çerçevesinde Değerlendirilmesi, s. 53; KAÇAN, Gizem, Avrupa İnsan Hakları Mahkemesi ve Türk Mahkemeleri Kararları Işığında Cinsel Yönelim Temelinde Ayrımcılık Yasağı, Onikilevha Yayınevi, İstanbul, 2020. s. 55; Benzer görüş için bkz. Yargıtay 18. CD. 30.03.2016, 2015/26353 E. 2016/6373 K.; 5237 sayılı Kanun'un 122'nci maddesinde yer alan suç tipinin dayanağı olan eşit işlem görme ve ayırımcılık yapılmamasını isteme hakkı, 1982 Anayasası ve Uluslararası sözleşmelerde yer almaktadır. 1982 Anayasası’nın 10'uncu maddesinde düzenlenen "Kanun önünde eşitlik" hükmü ayırımcılık yasağının Türk hukukundaki temelini oluşturmaktadır. Ayırımcılık yasağı, Medeni ve Siyasi Haklar Sözleşmesi’nin 2’nci maddesi ve Avrupa İnsan Hakları Sözleşmesi’nin 14'üncü maddesinde düzenlenmiştir. Temel ilke olan hukuk devleti ilkesinin bir gereği olarak 
yararlanmasının engellenmesiyle birlikte ayırımcılık ifadesi kavramsallaşmaya başlamıştır. Bu nedenle ulusal ve uluslararası düzenlemelerde ayırımcılık yasağı anlayışı doğrudan eşitlik ilkesiyle birlikte değerlendirilmektedir. ${ }^{23}$

\section{NEFRET SAIKININ AYIRIMCILIK SUÇUNA ETKISi}

\section{A. Genel Açıklamalar}

6529 sayılı Kanun'la birlikte 5237 sayılı Kanun'un 122'nci maddesinde yer alan ayırımcılık suçunun başlı̆̆ına ve metin kısmına eklenen nefret saikinin, suçun hukuki niteliğine, suçla korunan hukuki yarara, ayırımcılık kavramına, suçun manevi unsuruna, nefret saikine ilişkin modele ve suçun ispatına yönelik etkileri olmaktadır.

\section{B. Suçun Hukuki Niteliğine Etkisi}

5237 sayılı Kanun'un 122'nci maddesinde yer alan nefret ve ayırımcılık suçunun hukuki niteliğinin belirlenmesi, ceza normunun kapsamına, suçun unsurlarına ve koruduğu hukuki değerlerin belirlenmesine katkı yapmaktadır. Bu nedenle suç tipinin, nefret suçu ya da ayırımcılık suçu olup olmadığının tespit edilmesi gerekmektedir.

Nefret suçu ve ayırımcılık suçu benzer özellikler içermesine karşın farklı kavramlardır. Kavramların çoğunlukla birbirinden ayırt edilememesinin ana nedeni, konunun hukuksal boyutundan öte sosyolojik, kriminolojik ve psikolojik boyutlarının tartışılmasıdır. ${ }^{24}$

5237 sayılı Kanun'da nefret suçu ve ayırımcılık kavramları tanımlanmamıştır. Bu nedenle doktrinde, yargı kararlarında ve uluslararası belgelerde kabul gören tanımlamaların göz önünde bulundurulması gerekmektedir.

Tehdit, cebir, kasten yaralama, kasten öldürme, cinsel saldırı, mala zarar verme gibi şiddet içeren suç tiplerinin, belli bir topluluğa mensup olmaktan, bir aidiyet olgusundan kaynaklanan ön yargı saiki işlenmesi nefret suçudur. ${ }^{25}$ Ayırımcılık ise ırk, etnik köken, cinsiyet, din vb. birtakım sebeplerden

eşitlik ilkesi çerçevesinde, bireylerin ayırımcllı̆̆a tabi olmadan kanun önünde eşit olmaları güvence altına alınmıştır. KARAN, Ulaş, “Türk Hukukunda Ayrımcllı Yasağı ve Türk Ceza Kanunu’nun 122. Maddesinin Uygulanabilirliğı̈”, TBBD, 2007, Say1 73, s. 164.

23 DENIZ, s. 35; "Eşitlik ilkesi ve ayırımcılık yasağı, bazen yan yana ve bazen de aynı şeyi ifade etmek üzere kullanılabilen kavramlardır. Günümüzde eşitlik ilkesi insan haklarına ilişkin uluslararası sözleşmelerin ayrılmaz parçasıdır. Başka bir deyişle eşitlik ilkesi ve ayırımcılı yasağı, uluslararası hukukun en üstünde yer alan temel hukuk normu olarak kabul edilmektedir. Bu itibarla eşitlik ilkesi, hem başlı başına bir hak hem de diğer insan hak ve özgürlüklerinden yararlanılmasına hakim, temel bir ilke olarak kabul edilmektedir." Anayasa Mahkemesi, Tuğba Arslan, 25.06.2014, Başvuru No: 2014/256.

24 TÜRAY, Nefret Suçları ve Türk Ceza Hukukundaki Güncel Gelişmeler, s. 78.

25 SOKULLU, s. 103; ALEXANDER, s. 158; TÜRAY, Nefret Suçları ve Türk Ceza Hukukundaki Güncel Gelişmeler, s. 79; TANERİ, s. 666; İNCEOĞLU, Türk Ceza Kanunu’nun 122. Maddesinde Düzenlenen Nefret ve Ayrımcıllk Suçunun "Nefret Suçu" Kavramı Çerçevesinde Değerlendirilmesi, s. 43; ÖZTÜRK, s. 143. 
kaynaklı olarak bir gruba ya da grubun üyelerine karşı hukukun izin vermediği haksız tutum ve davranışlarda bulunulmasıdır. ${ }^{26}$

Avrupa İnsan Hakları Mahkemesi’ne göre nefret suçu ifadesi, bir suç tipinden öte bir kavramı tanımlamaktadır. Ön yargı saiki ile işlenen tüm fiilleri kapsaması amacıyla kullanılmaktadır. Nefret suçlarını diğer adi suçlardan ayıran failin sahip olduğu ön yargı saikidir. Ceza kanunları toplumdan topluma benzerlik göstermese de nefret suçunu oluşturan fiil, şiddet içerikli olup cezalandırılmalıdır. Ön yargı saiki ile işlenen kasten öldürme, kasten yaralama, ayırımcllık, mala zarar verme, tehdit, cinsel saldırı gibi soyut veya somut şiddet içeren suçlar birer nefret suçu olabilir. ${ }^{27}$ Avrupa İnsan Hakları Mahkemesi’ne göre ayırımcılık suçu ise, kişiye yapılan, makul ve geçerli bir nedene dayanmayan, meşru bir amaç taşımayan farklı bir muamelenin, ceza kanununda yer almasıdır. ${ }^{28}$

Yukarıda görüldüğü gibi nefret suçu ayırımcılıktan beslenir ancak nefret suçu, ayırımcılıktan daha net eylemler olarak kabul edilmektedir. ${ }^{29}$

Doktrinde yer alan çoğunluğun görüşüne göre 5237 sayılı Kanun'un 122’nci maddesinde yer alan nefret ve ayırımcıllk suçu, bir nefret suçu değildir. Fiilin nefret suçu olabilmesi için nefret saikine bağlı olmaksızın işlenebilen bağımsız bir suç tipinin varlığı gerekmektedir. Oysa 122'nci maddede yer alan nefret ve ayırımcllık suçunda nefret saiki suçun unsuru olduğundan, eksikliği halinde bağımsız bir suç tipi olarak ayırımcllık suçu işlenememektedir. ${ }^{30}$ Nefret suçunda, nefret saiki suçun unsuru olmadığından saik ortadan kalksa bile failin, bağımsız suçun temel unsurundan dolayı sorumluluğu devam etmektedir. Oysa ayırımcılık suçunda ayırımcılık saiki suçun unsuru olduğundan, saikin ortadan kalkmasıyla birlikte ayırımcılık suçu oluşmamaktadır. ${ }^{31} 122$ 'nci maddede yer alan fiilin ayırımclık suçunu oluşturması için, suçun manevi unsuru nefret saiki değil ayırımcllık saiki olmalıydı. Nefret suçunu oluşturması için de nefret saiki suçun unsuru olarak değil, suça etki eden bir nitelikli hal olarak yer almalıydı. Bu nedenle 122'nci maddede yer alan suç, teknik anlamda ne bir nefret suçu ne de ayırımcılık suçudur. Normda yer alan fiil için nefret saikiyle işlenen ayırımcılık suçu nitelendirmesi uygun düşmektedir. ${ }^{32}$ Benzer gerekçeyi savunan Yargitay’a göre de nefret ve

26 İNCEOĞLU, Asuman Aytekin, Nefret ve Ayırımclık, Özel Ceza Hukuku Cilt III, Hürriyete, Şerefe, Özel Hayata, Hayatın Gizli Alanına Karşı Suçlar, On İki Levha Yayınevi, İstanbul, 2018, s. 338.

27 Bkz. AİHM, Talpis v. İtalya, 02. 03.2017, Başvuru No: 41237, Par. 149; AİHM, K1lıç v. Türkiye, 28.06.2016, Başvuru No: 63034/11, Par. 120-121; AİHM, Opuz v. Türkiye, 09.06.2009, Başvuru No: 33401/02, Par. 200-201.

28 Bkz. AİHM, Marckx v. Belçika, 13.06.1979, Başvuru No: 6833, Par. 33.

29 SCHIEMANN, s. 270.

30 KOCASAKAL, s. 35; Benzer görüş için bkz. TÜRAY, Nefret Suçları ve Türk Ceza Hukukundaki Güncel Gelişmeler, s. 91; ERSOY, "Nefret ve Ayrımcılık Suçu (TCK m.122)", s. 52; YURTCAN, s. 176; BULUT, İlhan, Nefret Suçları, Adalet Yayınevi, Ankara, 2014, s. 153; İNCEOĞLU, Türk Ceza Kanunu’nun 122. Maddesinde Düzenlenen Nefret ve Ayrımcllı Suçunun "Nefret Suçu" Kavramı Çerçevesinde Değerlendirilmesi, s. 54; ÖZTÜRK, s. 140; ÇIÇEK, s. 138; YAŞAR/ GÖKCAN/ARTUÇ, s. 4061; SOKULLU, s. 103.

31 SOKULLU, s. 103.

32 ERSOY, "Nefret ve Ayrımcilık Suçu (TCK m.122)", s. 10; YURTCAN, s. 176; BULUT, s. 153; İNCEOĞLU, Türk Ceza Kanunu’nun 122. Maddesinde Düzenlenen Nefret ve Ayrımcilık Suçunun "Nefret Suçu" Kavramı Çerçevesinde Değerlendirilmesi, s. 54; TÜRAY, Nefret Suçları ve Türk Ceza Hukukundaki Güncel Gelişmeler, s. 92; ÖZTÜRK, s. 140; ÇIÇEK, s. 138; KOCASAKAL, s. 9; YAŞAR/GÖKCAN/ARTUÇ, s. 4061; SOKULLU, s. 103. 
ayırımcılık suçu, nefret suçu ya da ayırımcılık suçu olarak değil, "nefrete dayalı ayırımcılık suçu” olarak tanımlanmalıdır. ${ }^{33}$

Doktrinde yer alan azınlığın görüşüne göre nefret suçunda, bir farklılık veya mensubiyet nedeniyle ayırımcılığa tabi tutma vurgusu yapıldığından, nefret ve ayırımcılık suçu tipik bir nefret suçudur. ${ }^{34}$ 6529 sayılı Kanun'un gerekçesine göre 5237 sayılı Kanun'un 122’nci maddesinde yer alan fiil, ayırımcılık suçuyla birlikte aynı zamanda bir nefret suçudur. $\mathrm{Bu}$ nedenle nefret ve ayırımcılık suçunun düzenlendiği ceza normu, karma düzenlemedir. Suçun seçimlik hareketlerine bakıldığında ayırımcılık suçu; saike bakıldığında ise nefret suçu olarak nitelendirilebilmektedir. ${ }^{35} 5237$ sayılı Kanun'un 122'nci maddesinde yer alan suç tipinin, nefret suçu olduğunu savunan görüş doktrinde eleştirilmektedir. Nefret ve ayırımcılık suçunun, nefret suçu olduğunu savunanların gerekçesi hukuksal olmaktan öte lafzidir. Ceza normunda yer alan nefret saikinden yola çıkılarak suçun hukuki nitelendirmesi yapılmaktadır. Oysa normda yer alan nefret saiki, suç tipinin nefret suçu olduğunu kanıtlamamaktadır. Normda yer alan nefret saiki, bir farklılık veya mensubiyetten kaynaklanan ve açık bir şekilde düşmanlığı, hoşgörüsüzlüğü ortaya çıkartan sadece bir nefret söylemidir. ${ }^{36}$ Nefret söylemi, nefret suçunda olduğunun aksine bir suç tipi değildir. Nefret söylemi, toplumun tümüne etkisi olan ve bir kişiye veya mensup olduğu gruba yönelik, aşağılayan, inciten, düşmanlık içeren, dışlayan söz veya sembollerdir. ${ }^{37}$ Benzer bir tanım Avrupa Konseyi Bakanlar Komitesi tarafından 30.10.1997 tarihli R (97) 20 sayılı kararında da yapılmaktadır. ${ }^{38}$ Ayırımcılık ve nefret söylemi, birbirinden farklı olmasına rağmen etkileşim içinde olan kavramlardır. Ayırımcılık, nefret söyleminin kökeni bazı durumlarda da sonucu olarak ortaya çıkmaktadır. ${ }^{39}$ Ancak ayırımcılık, nefret söyleminde olduğu gibi belli bir kalıba sahip değildir. ${ }^{40}$ Nelerin ayırımcılık olarak kabul edildiği, kanun koyucunun takdirine bağlı olarak 5237 sayılı Kanun'un 122’nci maddesinde yer aldığı gibi, ilgili ceza normunda somutlaştırılmaktadır. ${ }^{41}$

33 Bkz. Yargıtay 18.CD. 12.11.2016, 2015/26353 E, 2016/6373 K.; Benzer diğer karar için ayrıca bkz. Yargıtay 18. CD. 01.10.2019, 2018/1978 E, 2019/13554 K.

34 ÖZBEK/DOĞAN/BACAKSIZ, s. 483; Benzer görüş için bkz. ÖNER, s. 94; ÇALIŞKAN, s. 183.

35 ŞAHINKAYA, s. 191.

36 UYGUN, Oktay, “Nefret İfadesi ve İfade Özgürlüğü”, GÜHFD, 2008, Cilt: 7, Sayı: 1, s. 8.

37 SCHIEDERMAIR, Stephanie, "Avrupa İnsan Hakları Mahkemesi Kararları Işığında Nefret Söylemi”, (Çeviren Özdem Özaydın), FHD, 2019, Cilt: 11, Sayı: 115, s. 6; ŞAHINKAYA, s. 8; ÖZBEK/DOĞAN/BACAKSIZ, s. 482; Nefret suçu ve nefret söylemi kavramı sıklıkla birbiriyle karıştırılmaktadır. Nefret suçu ve nefret söylemi benzer kavramlar değildir. Nefret söylemi, nefret suçunun işlenmesinin çıkış noktası; nefret suçunun işlenmesine neden olan saikin dışa vurumudur. Nefret söylemi, nefret suçunda failin saiki olup nefret suçunun işlenmesine zemin hazırlamaktadır. TÜRAY, Nefret Söylemi Bağlamında Halkı Kin ve Düşmanlığa Tahrik Suçu, s. 56.

Bkz."Nefret söylemi kavramı, ırkçı nefreti, yabancı düşmanlı̆ııı, Yahudi düşmanlı̆̆ını veya azınlıklara, göçmenlere ve göçmen kökenli insanlara yönelik saldirgan ulusalcllk ve etnik merkezcilik, ayırımcllk ve düşmanlik şeklinde ifadesini bulan, dinsel hoşgörüsüzlük dâhil olmak üzere hoşgörüsüzlüğe dayalı başka nefret biçimlerini yayan, kışkırtan, teşvik eden veya meşrulaştıran her türlü ifade biçimini kapsayacak şekilde anlaşılacaktır. Bu anlamda "nefret söylemi" muhakkak belirli bir kişiye veya gruba yönlendirilmiş yorumları kapsamaktadır." ERSOY, Uğur, "Çağımızın Pandemisi: Nefret Suçları", TAAD, Yll: 2018, S: 35, s. 120. 
Mukayeseli hukukta da nefret suçuna ilişkin düzenlemeler bulunmaktadır. İngiltere’de 1998 tarihli Suç ve Düzensizlik Kanunu, ikinci bölüm 28-32'nci paragraflara göre, rrk veya dine dayalı nefret saiki ile taciz, tehdit, kasten yaralama, mala zarar verme suçlarının işlenmesi durumunda ceza sorumluluğu artırılmaktadır. ${ }^{42} 2003$ tarihli Ceza Adaleti Kanunu madde 146'ya göre cinsel yönelim ve engellilikten kaynaklanan nefret saiki ile taciz, tehdit, kasten yaralama, mala zarar verme suçlarının işlenmesi durumunda da cezanın artırılacağı hüküm altına alınmıştır. ${ }^{43}$ Belçika’da 2007 tarihli Ayırımcllıkla Mücadele Kanunu madde 33-42'ye göre ırk, ten rengi, soy, ulusal veya etnik köken, cinsiyet, cinsel yönelim, evlilik durumu, doğum, yaş, malvarlığı, inanç veya hayat felsefesi, mevcut ve gelecekteki sağlık durumu, engellilik durumu, dil, siyasi görüş veya fiziksel ya da genetik özellikler veya toplumsal kökenden kaynaklanan nefret, aşağılama veya düşmanlık saikiyle; sarkıntılık ve tecavüz, kasten öldürme ve kasten yaralama, tehlikedeki bir kişiye yardım etmeme, kişisel özgürlüğün ve özel mülkün dokunulmazlığının ihlali, pusu veya tuzak kurmak, iftirada bulunma, kundakçllık ve kişisel eşyaların veya mülkün tahrip edilmesi suçlarının işlenmesi halinde ceza sorumluluğu artırılmaktadır. ${ }^{44}$ Kanada Ceza Kanunu’nun, 718/2 - i maddesine göre, rrk, ulusal ya da etnik köken, dil, renk, din, cinsiyet, yaş, zihinsel veya fiziksel engellilik, cinsel yönelim veya benzeri herhangi bir etmenden kaynaklanan taraflılık, ön yargı veya nefret saikiyle ceza kanununda yer alan suçların işlenmesi durumu ceza sorumluluğunu artıran neden olarak düzenlenmiştir. ${ }^{45}$ Hırvatistan Ceza Kanunu'nun, Tanımlar başlıklı 87'nci maddesinin, 20'nci maddesinde nefret suçu tanımlanmıştır: Nefret suçu, bir kişinin ırkı, rengi, dini, ulusal veya etnik kökeni, engelliliği, cinsiyeti, cinsel yönelimi veya cinsel kimliği nedeniyle işlenen tüm suçları ifade etmektedir. Söz konusu saikle ceza kanununda yer alan suçların işlenmesi durumu ceza sorumluluğunu artıran neden olarak düzenlenmiştir. ${ }^{46}$ Rusya Ceza Kanunu’nun, Ağırlaştırıcı Haller başlıklı 63/f maddesine göre, siyasi, ideolojik, ırkçı, etnik veya dini nefret veya düşmanlık saiki veya herhangi sosyal bir gruba yönelik nefret veya düşmanlık saiki ile ceza kanununda yer alan suçların işlenmesi halinde sorumluluk artırılmaktadır. ${ }^{47}$ Suç tiplerinde görüldüğü gibi nefret saiki, suçun unsuru olarak değil suçun nitelikli hali olarak düzenlenmiştir. Somut olayda nefret saiki bulunmasa dahi, normda düzenlenmiş olan bağımsız suç tipinden dolayı kişi yine de cezalandırılabilmektedir.

\section{Suçla Korunan Hukuki Yarara Etkisi}

Ayırımcılık suçunda, ceza normunda yer alan ayırımlardan dolayı kişilerin hak ve özgürlüklerden yararlanabilme hakkı gasp edilmektedir. Bu nedenle 6529 sayılı Kanun değişikliğinden önce suçla korunan hukuki yarar, toplum içinde mevcut olan farklılıklardan dolayı ayırım yapılmasının engellenerek, kişilerin hak ve özgürlüklerinden keyfi olarak yoksun bırakılmalarının

42 Bkz. Crime and Disorder Act, Second Part, Par. 28-32.

43 Bkz. Criminal Justice Act, Art. 146.

44 Bkz. Anti-Discrimination Law, Art. 33-42.

45 Bkz. Canadian Penal Code, Purpose and Principles of Sentencing, Art. 718/2-i.

46 Bkz. Croatian Penal Code, Meanıng of Terms Used in This Act, Art. 87, Par. 20.

47 Bkz. Russian Penal Code, Circumstances Aggravating Punishment, Art. 63/f. 
engellenmesiydi. ${ }^{48}$ Değişiklikten sonra, ayırımcılık suçunun başlı̆̆ına ve metin kısmına nefret saikinin eklenmesiyle birlikte suçla korunan hukuki yararının kapsamı genişlemiştir. Kanun koyucu, ayırımcılık suçunda kamu barışını da korumayı amaçladığından ceza normuna nefret saiki eklenmiştir. ${ }^{49}$ Nefret duygusuna bağlı farklılıklar koruma altına alınarak, nefret kaynaklı ayırımcılığın yapılmasının engellenmesi suretiyle failin, mağduru kullanarak toplumun bir kesimini ötekileştirmesi engellenmek istenmektedir. Bu şekilde toplumsal yaşamın ve barışın devamı da sağlanmaya çalışılmaktadır. ${ }^{50}$

\section{Ayırımcılık Kavramına Etkisi}

5237 sayılı Kanun'un 122'nci maddesine nefret saikinin eklenmesiyle birlikte kanun koyucu, ceza normunda yer alan fiilin nefret suçunu oluşturduğunu açıkça vurgulamak istemiştir. ${ }^{51}$ Ceza normunda yer alan bir suç tipinde, "nefret" ifadesi kullanılmamaktaysa, nefret saiki suçun unsuru olarak kabul edilmez. ${ }^{52}$ Madde metninde nefret saikine yer verilmeyen bir suç tipi, her ne kadar nefret suçu olarak anılsa da nefret saiki genellikle suçun unsurlarıyla ilgisiz olduğundan nefret saikiyle ilgili araştırma yapılmaz. ${ }^{53} \mathrm{Bu}$ nedenle kanun koyucu ayırımcılık suçunda nefret saikini, açıç̧a suçun başlığına ve metnine eklemek suretiyle, suçun unsuru olduğunu vurgulayarak nefret kavramının görünür olmasını hedeflemektedir. ${ }^{54}$

6529 sayılı Kanun değişikliğiyle birlikte her ne kadar nefret kavramının görünür olması arzu edilmiş olsa da bu durum ayırımcılık kavramını da etkilemiştir. 5237 sayılı Kanun'un 122'nci maddesinde yer alan fiil ayırımcılık suçunu oluşturmaktadır. Suçun başlığında ayırımcılık ifadesi yer almasına rağmen, nefret saikinin başlığa eklenmesiyle birlikte nefret kavramı öne çıkmakta, ayırımcılık kavramı geri planda kalmaktadır. ${ }^{55}$

Nefret, ayırımcılığa göre lafzi olarak daha etkili bir kavramdır. Bu durum ayırımcılığın, suç tipi olarak algılanmasına engel oluşturabilmektedir. Toplumsal algı açısından nefret ve ayırımcılık suçu, sadece nefret suçu olarak değerlendirilebilmektedir. ${ }^{56}$

Nefret saikinin eklenmesiyle birlikte sadece ayırımcılık yapılması değil, ayırımcılı̆̆ın dayanağının failin duyduğu nefretten kaynaklanması da aranmaktadır. ${ }^{57} \mathrm{Bu}$ durum ayırımcılık suçunun

48 BAYRAKTAR, s. 71; ERSOY, "Nefret ve Ayrımcllık Suçu (TCK m.122)", s. 32; KARAN, Türk Hukukunda Ayrımcllı Yasağı ve Türk Ceza Kanunu’nun 122. Maddesinin Uygulanabilirliği, s. 165; UYGUN, s. 10; TANERİ, s. 662; ÖZBEK/ DOĞAN/BACAKSIZ, s. 484; HAFIZOĞULLARI/ÖZEN, s. 225; YAŞAR/GÖKCAN/ARTUÇ, s. 4058.

49 KOCASAKAL, s. 21.

50 İNCEOĞLU, Nefret ve Ayrımcılık, s. 354; Benzer görüş için bkz. DEMİRBAŞ, s. 2695; MEMİş, s. 73; Benzer görüş için bkz. Yargitay 18. CD. 07.12.2016, 2015/33232 E 2016/18820 K.

51 ERSOY, "Nefret ve Ayrımcillk Suçu (TCK m.122)", s. 16.

52 ÇALIŞKAN, s. 184.

53 SCHIEMANN, s. 270.

54 ERSOY, "Nefret ve Ayrımcilık Suçu (TCK m.122)", s. 16.

55 KOCASAKAL, s. 36.

56 KOCASAKAL, s. 36.

57 ÖZBEK/DOĞAN/BACAKSIZ, s. 482. 
düzenlendiği ceza normunun koruma alanının, ayırımcılıkla birlikte nefret saiki özelinde düzenlenmesine neden olmuştur. ${ }^{58}$

\section{E. Suçun Manevi Unsuruna Etkisi}

Nefret ve ayırımcılık suçu, kasten işlenebilen bir suçtur. Suç tipinde yer alan maddi unsurların fail tarafından bilerek ve istenerek gerçekleştirilmesi gerekir. ${ }^{59}$

Suç genel teorisinde saik, kasttan önce oluşan ve kastı hazırlayan duygu ve düşüncedir. ${ }^{60}$ Kişi, hareketi mutlaka belli bir saikle yaptığı için kişinin suç işleme saiki, ilke olarak hukukun dişında kalmaktadır. ${ }^{61}$ Suç işleme saikinin ceza hukukunda öneminin olması için ceza normunda yer alması gerekmektedir. ${ }^{62}$ Normda yer alan saik, özel kast olarak nitelendirilmektedir. ${ }^{63}$ Özel kast olarak nitelendirilen saik, bir suçun temel şekline göre cezanın artırılmasını veya indirilmesini gerektiren bir nitelikli unsur olarak ya da doğrudan suçun unsuru olarak aranmış bulunmaktadır. ${ }^{64}$

6529 sayılı Kanun'la birlikte nefret kavramı, suçun başlığına ve metin kısmına suçun manevi unsuru açısından önemli olacak şekilde eklenerek, suçun nefrete dayalı ayırımcılık suçu olduğu açıkça vurgulanmıştır. ${ }^{65}$ Nefret ve ayırımcılık suçunda failin, ceza normunda yer alan hareketlerden en az birini dil, ırk, milliyet, renk, cinsiyet, engellilik, siyasi düşünce, felsefi inanç, din veya mezhep farklılığından kaynaklanan nefret saiki ile işlemesi gerekir. ${ }^{66}$ Bu nedenle nefret saiki, 122'nci maddede özel kast olarak değerlendirilmektedir. ${ }^{67}$ Nefret saiki, suça etki eden bir neden olarak değil, suçun manevi unsuru olarak kabul edilmektedir. ${ }^{68}$

58 TÜRAY, “Nefret Suçları ve Türk Ceza Hukukundaki Güncel Gelişmeler”, s. 62.

59 TÜRAY, Nefret Suçları ve Türk Ceza Hukukundaki Güncel Gelişmeler, s. 91.

60 KOCA, Mahmut/ÜZÜLMEZ, İlhan, Türk Ceza Hukuku Genel Hükümler, Seçkin Yayınevi, Ankara, 2020 , s. 145.

61 HAKERİ, Hakan, Ceza Hukuku Genel Hükümler, Adalet Yayınevi, Ankara, 2021, s. 207.

62 ARTUK, Mehmet Emin/GÖKCEN, Ahmet/ALŞAHİ, Mehmet Emin/ÇAKIR, Kerim, Ceza Hukuku Genel Hükümler, Adalet Yayınevi, Ankara, 2020, s. 410.

63 CENTEL, Nur/ZAFER, Hamide/ÇAKMUT, Özlem, Türk Ceza Hukukuna Giriş, Beta Yayınevi, İstanbul, 2020 , s. 380.

64 ARTUK/GÖKCEN/ALŞAHİ/ÇAKIR, s. 410.

65 KOCASAKAL, s. 9.

66 MEMİş, s. 79; 5237 sayılı Kanun'da nefretin suçun unsuru olarak düzenlendiği tek suç nefret ve ayırımcılık suçudur. DEMIRBAŞ, s. 2698.

67 BAYRAKTAR, s. 79; YURTCAN, s. 177; ÇIÇEK, s. 129; ÇALIŞKAN, s. 187; ERSOY, "Nefret ve Ayrımcılık Suçu (TCK m.122)", s. 45; KOCASAKAL, s. 35; TANERİ, s. 668; İNCEOĞLU, Türk Ceza Kanunu'nun 122. Maddesinde Düzenlenen Nefret ve Ayrımcılık Suçunun "Nefret Suçu” Kavramı Çerçevesinde Değerlendirilmesi, s. 58; HAFIZOĞULLARI/ ÖZEN, s. 226; ÖZTÜRK, s. 132; YAŞAR/GÖKCAN/ARTUÇ, s. 4061; Benzer görüş için bkz. Yargıtay 18. CD. 01.10.2019, 2018/1978 E, 2019/13554 K. Aksi görüş için bkz. Fiilin suç tipi haline getirilmesindeki amaç, failin sahip olduğu nefret saiki ile ayırımcılığın önüne geçilmesinin istenmesidir. Metnin düzenleniş biçimine bakıldığında failin sahip olduğu saik, kastın özel kasta dönüşmesini değil aksine hareketin neticeye yönelmesini ifade etmektedir. ÖZBEK/DOĞAN/ BACAKSIZ, s. 488; Bu görüş doktrinde eleştirilmektedir. Nefret saiki, hareketin neticeye yönelmesini sağlayan irade olarak değil failin harekete geçmesine neden olan irade olarak yorumlanmalıdır. Bu nedenle nefret saiki, fiil ile fail arasındaki psikolojik bağın içerisinde özel kast olarak değerlendirilmelidir. ERSOY, "Nefret ve Ayrımcılık Suçu (TCK m.122)", s. 45. 
6529 sayılı Kanun'la birlikte nefret kavramı, ayırımcılık suçunun başlı̆̆ına ve metin kısmına eklenmeden önce de ayırımcllık suçu özel kast ile işlenebilmekteydi. Ayırımcılı̆̆ın, ceza normunda sayılan dil, ırk, milliyet, renk, cinsiyet, engellilik, siyasi düşünce, felsefi inanç, din veya mezhep farklılığına dayalı olarak yapılması suçun manevi unsuru içerisinde değerlendirilmekteydi. ${ }^{69}$ Ayırımcilığın, normda sayılmış olan farkllılklar nedeniyle işlenmesi failin belli bir saikle hareket ettiğini göstermekteydi. ${ }^{70} 6529$ sayılı Kanun'la birlikte mevcut olan özel kast değiştirilmiştir. Normda gösterilen sebeplerden kaynaklanan nefrete bağlı olarak yapılacak ayırımclık, failin özel kastını oluşturmaktadır. ${ }^{71}$

\section{F. Nefret Saikine ilişkin Modele Etkisi}

Nefreti ortaya çıartan saike ilişkin olarak ceza kanunlarında nefret düzenlemesi, düşmanlık ve ayırımcı seçilim modelleri oluşturularak yapılmaktadır.

Düşmanlık modelinde, failin, ceza normunda korunan gruba karşı nefret saikiyle suç işlemesi gerekir. Örneğin "dil, rrk, milliyet, renk, cinsiyet, engellilik, siyasi düşünce, felsefi inanç, din veya mezhep farklılığından kaynaklanan nefret nedeniyle işlenmesi halinde" gibi ifade düşmanlık modelinin benimsendiğini göstermektedir. ${ }^{72}$ Ayırımcı seçilim modelinde ise failin suç işlemesinin nedeni, mağdurun ceza normunda korunan gruba mensup olmasıdır. ${ }^{73}$ Örneğin, "suçun, mağdurun belirli bir etnik grup, ulus, rrk veya dine, gerçek veya varsayılan üyeliği veya üye olmaması nedeniyle işlenmesi halinde" gibi ifade ayırımcı seçilim modelinin benimsendiğini göstermektedir. ${ }^{74}$

Normatif düzlemde iki model arasındaki fark, nefret saikinin suçun unsuru olarak aranıp aranmaması şeklinde formülize edilmektedir. Düşmanlık modelinde nefret, ceza normunda yer aldığından suçun unsurudur. Bu nedenle somut olayda nefretin varlığı kanıtlanmalıdır. Ayırımcı seçilim modelinde ise ceza normunda korunan grubun özelliği ile hareket arasında nedensellik bağlantısı olmasına rağmen nefret saiki kesin olarak belirtilmemiştir. Bu nedenle nefret, suçun unsuru olarak düzenlenmediği için somut olayda varlığının kanıtlanmasına gerek yoktur. ${ }^{75}$

Mağdurun belli bir gruba mensup olmasından dolayı hedef olarak seçilmesinin yarattığı infial ile mağdurun ilgili gruba duyulan nefret nedeniyle hedef olarak seçilmesinin yarattığı infial arasında fark

69 ŞEN, s. 363; 6529 sayılı Kanun değişikliğinden önce 122'nci maddede ayırımcılı̆̆ın nedeni “dil, rrk, milliyet, renk, cinsiyet, engellilik, siyasi düşünce, felsefi inanç, din veya mezhep ve benzeri sebepler" olarak ifade edilmekteydi. Ayırımcılık saikini oluşturan farklılıklar sınırlı sayıda gösterilmemişti. "Benzeri sebepler" ifadesinin ceza normunda bulunmasıyla birlikte, suçun manevi unsuru geniş yorumlanmaktaydı. BAYRAKTAR, s. 62; Açık ve belirli olmayan ifadeler, kıyas yapılmasına neden olabileceğinden hukuki güvenliği tehdit etmekteydi. Bu nedenle "benzeri sebepler" ifadesinin ceza normundan çıkartılması suçta ve cezada kanunilik ilkesine uygunluk açısından yerinde olmuştur. TÜRAY, Nefret Suçları ve Türk Ceza Hukukundaki Güncel Gelişmeler, s. 91.

70 KOCASAKAL, s. 9; Benzer görüs için bkz. KARAN, Türk Hukukunda Ayrımcllık Yasağı ve Türk Ceza Kanunu’nun 122. Maddesinin Uygulanabilirliği, s. 169.

71 MERAN, s. 559.

72 SAHINKAYA, s. 168.

73 TÜRAY, Nefret Suçları ve Türk Ceza Hukukundaki Güncel Gelişmeler, s. 83.

74 BULUT, s. 135.

75 TÜRAY, Nefret Suçları ve Türk Ceza Hukukundaki Güncel Gelişmeler, s. 84. 
bulunmamaktadır. Ancak ayırımcı seçilim modelinde nefret, suçun unsuru olarak aranmadığından suçun ispatlanabilme ihtimali düşmanlık modeline göre daha kuvvetlidir. ${ }^{76}$

Günümüz ceza hukuku anlayışında ayırımcı seçilim modeli ayırımcılık suçlarında yer alırken, düşmanlık modeli ise nefret suçlarında düzenlenmektedir. ${ }^{77} 6529$ sayılı Kanun değişikliğinden önce 122'nci maddede nefret, suçun unsuru olarak yer almadığından suç tipi ayırımcı seçilim modeli oluşturularak düzenlenmişti. Değişiklikle birlikte ceza normunda nefret saiki yer aldığından, nefret saikinin belirlenmesine ilişkin model değiştirilmiş ve kanun koyucu düşmanlık modelini tercih etmiştir. $^{78}$

\section{G. Suçun Ispatına Etkisi}

Nefret ve ayırımcılık suçunda dil, ırk, milliyet, renk, cinsiyet, engellilik, siyasi düşünce, felsefi inanç, din veya mezhep farklılığından kaynaklanan nefret saiki suçun unsuru olarak düzenlendiğinden, nefret saikiyle hareket edildiğinin kanıtlanması gerekmektedir. ${ }^{79}$ Özel kast olarak nitelendirilen ceza normunda yer alan suç işleme saiki, suç yolunda kişiyi harekete geçiren etken olup psikolojik olgunun irade aşamasını ilgilendirir. ${ }^{80}$ Saik, olaydan olaya değişen ve kişiye özgü nitelik gösterdiğinden her somut olayda tüm yönleriyle araştırılmalıdır. ${ }^{81}$

Nefret ve ayırımcllı suçunda somut olayda nefret saikinin belirlenmesi, ceza normuyla ilgili en önemli sorun olarak ortaya çımaktadır. ${ }^{82}$

Nefret saikinin, ayırımcılık suçunda manevi unsur olarak düzenlenmesi, suçun ispatını zorlaştırdığg gerekçesiyle doktrinde eleştirilmektedir. Kocasakal’a göre, 6529 sayılı Kanun değişikliğinden önce, ayırımcılık suçunda özel kast olarak nitelendirilen ayırımcılık saikinin belirlenebilmesi mümkündü. Failin dış dünyaya yansıyan somut, daha açık hareketlerinden, hal ve şartların haklı, mazur ve meşru göstermediği bir ayırımın yapılıp yapılmadığı anlaşılabilmekteydi. Diğer ifadeyle ayırımcılık saiki bir sonuç yansıması olduğundan kanıtlanması zor olmamaktaydı. Ancak kavram olarak farklı yorumlanabilen nefret saikinin kanıtlanabilmesi oldukça zor olmaktadır. ${ }^{83}$ İnceoğlu’na göre, suç tipine işlerlik kazandırmak, özellikle suç mağdurlarının korunması adına oldukça önemli olmasına rağmen nefret ve ayırımcllık suçu, suçun adının ve manevi unsurunun değiştirilmesi ve ispatının zorlaştırılmasından dolayı normatif yapı açısından yetersiz kalmaktadır. ${ }^{84}$ Taneri’ye göre, psikolojik

76 BENIER, s. 180 .

77 LAWRENCE, s. 380.

78 TÜRAY, Nefret Suçları ve Türk Ceza Hukukundaki Güncel Gelişmeler, s. 91.

79 İNCEOĞLU, Türk Ceza Kanunu’nun 122. Maddesinde Düzenlenen Nefret ve Ayrımcilık Suçunun "Nefret Suçu" Kavramı Çerçevesinde Değerlendirilmesi, s. 59.

80 CENTEL/ZAFER/ÇAKMUT, s. 380.

81 MORSCH, James, "The Problem of Motive in Hate Crimes: The Argument against Presumptions of Racial Motivation", Journal of Criminal Law and Criminology, 1991, Vol. 82, İss. 3, s. 666.

82 BULUT, s. 3.

83 KOCASAKAL, s. 35.

84 İNCEOĞLU, Türk Ceza Kanunu’nun 122. Maddesinde Düzenlenen Nefret ve Ayrımcllık Suçunun "Nefret Suçu” Kavramı 
özellikleri ayırımcılık saikine göre daha güçlü, zaman zaman patolojik bir hal olan; failin taşıdığı karmaşık bir duygu olan nefret saikinin kanıtlanabilmesi oldukça zordur. Bu nedenle 122'nci maddede ispatı oldukça zor olan bir suç tipi tanımlamaktadır. ${ }^{85}$ Türay’a göre nefret kavramı, psikolojik hal, bir duygu olup failin hareketlerine bakılarak ortaya çıkartılabilmesi oldukça zor olmaktadır. Soyut ve kanıtlanabilmesi oldukça zor olan bir duygunun, suçun unsuru olarak düzenlenmesi ceza normunun uygulama alanını daraltabilmektedir. ${ }^{86}$ Şahinkaya'ya göre, nefret saikinin kanıtlanmasının zorluğundan dolayı ayırımcılık suçu işlevsel olmaktan uzaktır. Suçun mağdurları, nefret saikini kanıtlayamama korkularından dolayı genellikle şikayet haklarını kullanmamaktadırlar. Şikayet edilmiş olsa dahi genel ve soyut ihbar veya şikayet nedeniyle soruşturma makamları iddiaları dikkate almamakta, soruşturma açılmamaktadır. Soruşturma veya kovuşturma başlatılan durumlarda da "ayırımcılığın sayılan farklılıklara duyulan nefret nedeniyle işlendiğgi" ispat edilemediği için, muhakemenin aşamasına göre, çoğunlukla kovuşturmaya yer olmadığı veya beraat kararı verilmekte ve ilk derece mahkemesinden verilen beraat kararlarının da onandığı görülmektedir. ${ }^{87}$

5237 sayılı Kanun'un 122'nci maddesinde yer alan nefret ve ayırımcılık suçu özelinde olmaksızın, ayırımcılık suçunda nefret saikinin yer almaması gerektiğine yönelik doktrinde görüşler bulunmaktadır. Dancygier/Green'e göre, nefret saikinin ayırımcılık suçunda unsur olarak yer alması, mağdurun ve mensup olduğu grubun yaşadığı psikolojik etkiyi değiştirmemektedir. Ayırımcılığın nedeni her ne kadar nefret saiki olsa da bu durum mağdurun ve mensup olduğu grubun dışlanmasının nedeni olan seçimlik hareketleri etkilememektedir. Mağdur üzerinde etkisi olmayan nefret kavramının suçun unsuru olarak düzenlenmesi gereksiz olmaktadır. İlave olarak, nefret kavramının, ön yargıya dayalı olarak işlenen suç gruplarını kategorileştirmeyi amaçlayan kriminolojik bir anlamı bulunmaktadır. Bu nedenle nefret kavramının bir suçta suçun unsuru olarak ayrıca ve açıkça düzenlenmesi, sahip olduğu kriminolojik rolüne zarar vermektedir. ${ }^{88}$ Hare'ye göre, fiili işleyen kişinin kastının somut olayda tespit edilebilmesi mümkün olmasına rağmen saik, niyet, amaç

Çerçevesinde Değerlendirilmesi, s. 59.

85

86

87 işlediğine dair dosyada katılanın soyut beyanları dışında başka bir delil bulunmamakla birlikte, katılanın konuşmaları esnasında orada olduğunu söylediği saniğın şoförü olan tanığın beyanlarında böyle bir konuşma olmadiğını, katılanın kendisini emniyette teşhis edemediğini söylediği, bu nedenle sanı̆̆ın müsnet suçtan mahkumiyetine yeterli, kesin ve inandırıcı delil elde edilemediğinden sanı̆̆ın beraatine karar verilmiştir.” Yargıtay 4. CD, 19.12.2012 gün, 2012/25278 E, 2012/30932 K. sayılı ilamı ile onaylanan Marmaris 2. Sulh ceza mahkemesi 01.03.2010 gün, 2009/746 E, 2010/67 K. sayılı ilamı. Benzer diğer kararlar için ayrıca bkz. "Yapılan yargılama, toplanan deliller nazara alınmak suretiyle olayın meydana gelişş̧ekli ve gelişimi de göz önüne alınmak suretiyle; olay günü sanığın daha önceki mevzuat gereği tanık uygulaması nedeniyle tanık talebinde bulunduğu, mevzuatın yeterince uygulanmaması ve söz konusu işlemin istisnai bir işlem olması sebebi ile sanı̆̆ın mevzuatı yakından takip edememesi veya bu konuda özel bilgilendirilmemiş olması nedeni ile tanı̆̆ın bulundurması hususunda ısrarlı davrandığı, zira kendisinin de tanığın bulunması için bizzat çaba sarf ederek tanı̆̆ın temininde etken olduğu, saniğın amacının müdahilin görme engelli olmasından kaynaklı olarak işlemini yapmamak, geciktirmek veya savsaklamak olmadığı, kast ve saikin buna yönelik olmadığı anlaşılmakla sanığa isnat edilen suç yönünden kasıt unsuru olan manevi unsur gerçekleşmediğinden beraat kararı verilmiştir.” Yargitay 4. CD, 14.01.2013 gün, 2012/11488 E, 2013/114 K. sayılı ilamı ile onaylanan Ankara 7. Sulh Ceza Mahkemesi 24.02.2010 gün, 2009/457 E, 2010/112 K. sayılı ilamı; Yargıtay 18. CD, 26.11.2018 gün, 2016/12031 E, 2018/15788 K. sayılı ilamı ile onaylanan Kuşadası 1. Asliye Ceza Mahkemesi 23.02. 2016 gün, 2014/345 E, 2016/208 K. sayılı ilamı.

DANCYGİER/GREEN, s. 498. 
gibi kastı oluşturan iradenin suçun manevi unsuru olarak kanıtlanabilmesi oldukça zor olmaktadır. $\mathrm{Bu}$ anlayışa göre mevcut ceza hukuku, ceza normunu failin kişiliğine uydurmaya çalışmaktadır. Oysa evrensel ceza hukukunda failin kastının ceza normuna uyup uymadığına göre sorumluluk değerlendirilmesi yapılmaktadır. ${ }^{89}$ Morsch'a göre, Devletler, koruma yükümlülüğü kapsamında, uluslararası sözleşmelerde yer alan hakların korunması için kanun koymak, önleyici tedbirler almak ve bunları uygulamakla yükümlüdür. Ayırımcılık suçu hemen hemen insan haklarına saygılı tüm uygar ülkelerin cezalandırdığı bir suç tipidir. Ayırımcılık yasağının öngörülmesi ve yasağın işler halde olması uluslararası yükümlülüktür. Nefret saikinin ayırımcılık suçunda yer alması, somut olayda ayırımcılık yasağının uygulanabilmesine imkan sağlamamaktadır. Bu nedenle nefret saikinin ayırımcılık suçunda suçun unsuru olarak yer alması, uluslararası hukuka yönelik taahhütlerin ihlali olarak değerlendirilebilmektedir. ${ }^{90}$

Nefret saikinin, ispatının zorluğuna bağlı olarak, hangi delillere dayanılarak belirleneceği tartışmanın esasını oluşturmaktadır. Saikin belirlenebilmesi için failin zihinsel durumuna göre bir değerlendirme yapılmalıdır. ${ }^{91}$ Ancak bunun nasıl yapılabileceğine dair ceza hukukunda herhangi bir model bulunmamaktadır.92

Nefret suçlarında faili motive eden nefret duygusudur. ${ }^{93}$ Ayırımcılık gibi suçlarda nefretin unsur olarak yer almasıyla birlikte, faili motive eden psikoloji konusunda soruşturma makamlarının çelişki yaşama ihtimali oldukça kuvvetlidir. ${ }^{94}$ Daha güçlü bir insan hakları koruma sisteminin oluşturulabilmesi amacıyla, 2021 tarihli İnsan Hakları Eylem Planı hazırlanmıştır. Nefret ve ayırımcılık suçunda fiilin cezasız kalmasını engellemek adına, etkin soruşturmanın yürütülmesi hedeflenmektedir. Soruşturmaların etkin yürütülmesi amacıyla veri tabanı oluşturulması, mağdurla iletişimin etkinleştirilmesi, istatistiklerin sağlıklı bir şekilde toplanması; kolluk ve savcılık personeline eğitim verilmesi planlanmaktadır.

Avrupa İnsan Hakları Mahkemesi’ne göre, nefret saikinin yer aldığı suç tiplerinde ön yargı saikinin varlığının kanıtlanmasında, soruşturma makamlarının etkin rol oynaması beklenmektedir. Saik sadece istatistiklerle kanıtlanabilecek basit bir durum değildir. Değişik türdeki deliller toplanmalı ve somut olayla birlikte değerlendirilmelidir. ${ }^{95}$ Soruşturma makamlarının ikna edici ve tatminkar araştırma yapmaları ${ }^{96}$ ve saikin yoğunluğunu araştırmalar1 ${ }^{97}$ beklenmektedir. Ancak nefret saikinin kanıtlanmasının zorluğundan dolayı, saikin kanıtlanmasına yönelik yeterli delil araştırılmamaktadır. ${ }^{98}$ Sadece ceza normunda yer alan ayırımcılık suçunu oluşturan seçimlik hareketlerin somut olayda

89 HARE, s. 435.

90 MORSCH, s. 660.

91 LAWRENCE, s. 371.

92 TÜRAY, Nefret Suçları ve Türk Ceza Hukukundaki Güncel Gelişmeler, s. 92.

93 DANNER, s. 413.

94 SCHİEMANN, s. 270.

95 Bkz. AİHM. D.H. ve Diğerleri v. Çek Cumhuriyeti (GC), 13.11.2007, Bașvuru No: 57325/00, Par. 187.

96 Bkz. AİHM. Nachova ve Diğerleri v. Bulgaristan (GC) 06.07.2005, Başvuru No: 43577/98 ve 43579/98, Par. 157.

97 Bkz. AİHM. Vallianatos ve Diğerleri v. Yunanistan (GC), 07.11.2013, Başvuru No: $\underline{29381 / 09}$ ve $\underline{32684 / 09}$, Par. 77.

98 JACOBS/HENRY, s. 384. 
bulunup bulunmadığı araştırılarak iddianame düzenlemektedir. Somut olayda nefret saikinin bulunup bulunmadığı kovuşturma aşamasında mahkeme tarafından araştıılmaktadır. Nefret saikinin varlığına yönelik deliller toplanıp değerlendirilmeden hazırlanmış olan bir iddianame, yargılama makamının ayırımcılık suçunu cezalandırmasına imkân tanımamaktadır. ${ }^{99}$

\section{H. Değerlendirme}

02.03.2014 tarih ve 6529 sayılı Kanun'la birlikte nefret saiki, ayırımcılık suçunun manevi unsuru olarak ceza normuna eklenmiştir. Değişiklikle birlikte 5237 sayılı Kanun’un ilk şeklinde ayırımcılık saikinin kaynağı olarak yasada koruma altına alınmış olan dil, ırk, milliyet, renk, cinsiyet, engellilik, siyasi düşünce, felsefi inanç, din veya mezhep grupları artık nefret saikinin kaynağı olarak kabul edilmektedir.

6529 sayılı Kanun'la yapılan değişiklikten önceki 5237 sayılı Kanun'un 122'nci maddesinde yer alan ayırımcllık suçunda dil, ırk, milliyet, renk, cinsiyet, engellilik, siyasi düşünce, felsefi inanç, din veya mezhep ve benzeri sebepler failin suç işleme saikini oluşturmaktaydı. Norm içerisinde bazı saikler sayıldıktan sonra "ve benzeri sebeplerle" ifadesinin kullanılması, kapsamı ciddi şekilde genişletmişti. Ceza normunda belirtilen saiklerin dahi, somut olay bakımından gerçekleştiğini ispatlamak oldukça güç iken sayılmayanların tespit edilmesi ve ispatlanması sıkıntılıydı. Kanun koyucu yerinde bir düzenleme yaparak 6529 sayılı Kanun değişikliğiyle "ve benzeri sebeplerle" ifadesini kaldırmıştır.

6529 sayılı Kanun değişikliğiyle birlikte nefret saiki, ceza normunda özel kast olarak düzenlenmiştir. Failin, 122'nci maddede belirtilen seçimlik hareketlerden en az birini dil, ırk, milliyet, renk, cinsiyet, engellilik, siyasi düşünce, felsefi inanç, din veya mezhep farklllığından kaynaklanan nefret saiki ile işlemesi gerekmektedir.

Nefret saikinin norma eklenmesiyle birlikte, nefret kaynaklı ayırımcılığın yapılması engellenmek istenmektedir.

Nefret saikinin suçun unsuru olarak yer aldığı bir ceza normunun etkili olması için, öncelikli olarak nefret saikinin norma eklenmesinin amacının, normun uygulamasının nasıl olacağının, nefret saikinin ilgili normu daha $\mathrm{m} ı$ az yoksa daha $\mathrm{m}$ çok kullanılabilir hale getirdiğinin dikkate alınması gerekmektedir.

Nefret saikinin ayırımcllık suçuna eklenmesine ilişkin olarak madde gerekçesinde yeterli izahat bulunmamaktadır. Kanun koyucunun nefret saikini ayırımclık suçuna ilişkin norma eklemesi, hem hukuksal hem de sosyolojik açıdan değerlendirilebilmektedir.

Hukuksal değerlendirmeye göre, 6529 sayılı Kanun değişikliğinden önceki ayırımcllık suçunun kapsamı, cezalandırmada adaleti sağlamamaktadır. Ayırımcılık fiilini oluşturan norm, amacının dışında uygulanabilmektedir. Bu nedenle kanun koyucu, ön yargının kaynağı olan dil, ırk, milliyet, 
renk, cinsiyet, engellilik, siyasi düşünce, felsefi inanç, din veya mezhep farklıllğına bağlı olarak Kanun'da yer alan seçimlik hareketlerin gerçekleşmesi ihtimalini, amacının dışında cezalandırmak istememektedir. Örneğin, apartmanda yer alan kişilerin huzur ve sükunun sağlanması amacıyla bekar olan birisine evin kiraya verilmemesi; bayanların çoğunlukta olduğu bir iş yerinde bir erkeğin işe alınmaması; kıskançlığa bağlı olarak bir erkeğin işe alınmaması; kişinin dini inancından dolayı, ateist olan birisine evini kiralamak istememesi halleri sadece bir düşünce açılaması, bir tercih nedeni olarak yorumlanabilmesine rağmen ayırımcılık suçundan dolayı cezalandırılabilmekteydi. Nefret saikinin eklenmesiyle birlikte sadece bir düşünce ya da tercihin cezalandırılması engellenmek istenmektedir. Nefret saikiyle işlenen bir suç; nefret saiki olmadan işlenebilen suçlara göre daha tehlikelidir. Nefret saikinin ayırımclık suçuna eklenmesiyle birlikte kanun koyucu, mağduriyet yaşanmaması adına, mevcut ayırımcılık suçunun işlenmesinin kolay olma ihtimalini düşünerek suçun işlenmesini zorlaştırmış ve fiilin yoğun tehlike içermesini yaptırıma bağlamıştır. Bu durum 6529 sayılı Kanun değişikliğiyle birlikte suçun cezasının artırılmasında ve seçimlik ceza olan adli para cezasının kaldırılmasında da kendisini göstermektedir.

Sosyolojik değerlendirmeye göre, nefret ve ayırımcllı suçunda kanun koyucu ceza normunda sayılan gruplara yönelik negatif algıyı değiştirmek amacıyla grupları görünür kılmaktadır. Bu nedenle nefretin kaynağı olan gruplar ceza normunda açıkça sayılmıştır. Nefret saikinin norma eklenmesiyle birlikte grup üyelerine yönelik ayırımcllıktan öte nefret saiki vurgulanmaktadır. Nefret ibaresi suçun unsuru olarak düzenlemek suretiyle normun güçlü ve etkili olması arzu edilmektedir.

5237 sayılı Kanun'un 122 'nci maddesinde nefret saikinden kaynakl1, ayırımcilığa neden olan hareketler cezalandırılmaktadır. Norm, farklılıklardan kaynaklanan nefret saiki ile birlikte bazı engellemeleri de cezalandırmaktadır. Bu nedenle fiil, ayırımcılık suçunu oluşturmaktadır. Ayırımcılığa neden olan hareketler, dil, ırk, milliyet, renk, cinsiyet, engellilik, siyasi düşünce, felsefi inanç, din veya mezhep farklılığından kaynaklı nefret saikiyle gerçekleştirilmektedir. Failin, belli bir kişi ya da gruba karşı ön yargı duygusundan kaynaklı olarak ayırımclık yapılmaktadır. Bu nedenle 122'nci maddede yer alan fiil, ayırımcılık suçuyla birlikte aynı zamanda bir nefret suçu olarak da kabul edilmelidir.

Nefret suçunun oluşması için, ceza kanununda yer alan bağımsız bir suç tipinin varlı̆̆ının aranmasının hukuksal bir anlamı bulunmamaktadır. Bu anlayışa göre, nefret saiki suçun sadece nitelikli hali olduğunda nefret suçu oluşmaktadır. Nefret saikinin, suçun unsuru ya da nitelikli hali olarak ceza normunda yer alması ya da ceza normunda hiç yer almaması, fiilin nefret suçu olarak nitelendirilmesinde veya nitelendirilmemesinde önem taşımamaktadır. Bir kişinin ya da grubun, sahip olduğu varsayılan farklı özelliklerine duyulan ön yargı ile soyut veya somut şiddet içeren her suç tipi, nefret suçu olarak ifade edilebilmektedir. Benzer bir değerlendirme Avrupa Güvenlik ve İşbirliği Teşkilatı tarafından da yapılmaktadır. ${ }^{100}$

100 "Nefret suçu; mağdurun mülkün ya da işlenen bir suçun hedefinin, gerçek veya hissedilen ırk, ulusal ya da etnik köken, dil, renk, din, cinsiyet, yaş, zihinsel ya da fiziksel engellilik, cinsel yönelim veya diğer benzer faktörlere dayalı olarak benzer özellikler taşıyan bir grupla gerçek ya da öyle algılanan bağı, bağhllğ̆, aidiyeti, desteği ya da üyeliği nedeniyle seçildiği, kişilere veya mala karşı suçları da kapsayacak șekilde ișlenen her türlü suçtur." Bkz. ŞAHINKAYA, s. 51. 
Ceza kanununda yer alan suçlar nefret duygusuyla işlenebilmektedir. Ancak nefret suçunu, nefret duyarak işlenen suçlardan ayırt eden temel özellik, belli bir ön yargıyı barındırmasıdır. Nefret suçunda odaklanılması gereken husus, suçun hedefinde olan kişi ya da gruba karşı duyulan ön yargıdır. Failin düşünce yapısı veya karakterinde, bir kişiye ya da gruba karşı ön yargı bulunmaktadır. Bu ön yargıya bağlı olarak, yasaklanmış olan fiil gerçekleştirilmektedir. Ön yargı saikine bağlı olarak kişi ya da grup dışlanmaktadır. Fail, mağduru, ön yargıyla ortaya çıkan duyguya bağlı olarak damgalamak ya da ötekileştirmek arzusunu taşımaktadır. Ceza kanununda yasaklanmış olan fiili gerçekleştirebilme hakkı meşru kabul edilmektedir. Sayılan özelliklerin tamamı, 5237 sayılı Kanun’un 122 'nci maddesinde düzenlenen suç tipinde yer aldığından, düzenleme ayırımcllık suçuyla birlikte aynı zamanda bir nefret suçu olarak da kabul edilmelidir.

Suç tipinde nefret saikinin, suçun manevi unsuru olarak kabul edilmesi, fiilin nefret suçu sayılmasına engel olmamaktadır. Nefret suçuna ilişkin normun oluşturulmasında belli bir yasal kriter bulunmamaktadır. Kanun koyucunun tercihine bağlı olarak ön yargı saiki, nitelikli hal veya suçun unsuru olarak düzenlenmiş ya da düzenlenmemiş olabilir. Örneğin, kasten yaralama suçunda nefret saiki, suçun unsuru ya da nitelikli hali olarak düzenlendiğinde fiil, kasten yaralama suçu olmasının yanında nefret suçu olarak da kabul edilebilecektir. Nefret suçu, kapsayıcı bir düzenlemedir. 6529 sayılı Kanun değişikliğiyle birlikte 5237 sayılı Kanun'un 122'nci maddesinde yer alan fiil, ayırımcılık suçuyla birlikte aynı zamanda bir nefret suçunu oluşturmaktadır.

Hak ve özgürlüklerden yararlanabilme hakkına yönelik bir saldırı söz konusu olduğundan ayırımcılık suçu, hürriyete karşı suçlar başlığı altında düzenlenmiştir. 6529 sayılı Kanun’la nefret saikinin ayırımclık suçuna eklenmesinin sonucu olarak, nefret saikinin, toplumsal bölünmelere neden olabilme ihtimalinden dolayı kanun koyucu aynı zamanda kamu barışını da korumayı amaçlamaktadır. Ancak bu durum nefret ve ayırımcılık suçunun, kamu barışına karşı işlenen suçlar başlı̆̆ı altında düzenlenmesinin gerekçesi olmamalıdır. Kamu barışına karşı işlenen suçlarda korunması amaçlanan, kamu düzeni veya kamu barışı şeklinde somutlaştırılmış, Devletin hukuki varlı̆̆ının garanti altına alınma düşüncesidir. Nefret ve ayırımcılık suçunda ise hedef, doğrudan kamu düzeni ya da kamu barışı olmayıp bir kişi ya da grubun sahip olduğu bazı hak ve hürriyetlerin gaspedilmesi düşüncesidir.

Nefret saikinin somut olayda kanıtlanmasının zorluğu gerekçe gösterilerek 122'nci maddede yer alan düzenleme eleștirilmektedir. Kanun koyucunun amacının nefret ve ayırımcıllk suçunu oluşturan fiilleri cezasız bırakmak olduğu düşünülemez. Yukarıda yer alan açıklamalarımızda da görüldüğü üzere düzenleme, hukuksal ve sosyolojik açıdan makul olarak karşılanmalıdır. Somut olayda sadece düşünce veya tercih olarak değerlendirilebilecek davranışların cezalandırılmamasıyla birlikte, nefret saikinin de cezalandırılması tercih edilerek normun etkili ve güçlü olması arzulanmaktadır. Nefret saikinin kanıtlanmasının zorluğu düşüncesi, nefret saikinin uygulamada yeni bir kavram olmasından kaynaklanan sadece bir algı olarak düşünülmelidir. Nefret ve ayırımcılık suçunda uygulama yerleştikçe, saikin ispatına yönelik belli bir anlayış da muhakkak oluşacaktır. Nefret saikinin, ayırımcılık suçunda yer almasıyla birlikte nefret suçlarına yönelik pozitif bir algı oluşmuştur. 2021 tarihli İnsan Hakları 
Eylem Planı’nda da yer aldığı üzere nefret saikinin ispatına yönelik neler yapılabileceği, uygulama kısmına nasıl katkı sağlanabileceğine yönelik düzenlemeler tartışılmaya başlanmıştır.

Nefret ve ayırımcılık suçunun etkin olarak uygulanabilmesi için nefret saikinin kanıtlanabilmesine ilişkin olarak birtakım görüşlerin ortaya konulması gerekmektedir.

Nefret ve ayırımcllık suçunda nefret saiki suçun unsuru olduğundan, hem soruşturmanın başlangıcında aranılan başlangıç şüphesi olan basit suç şüphesinin hem de iddianamenin düzenlenmesinde aranılan yeterli suç şüphesinin nefret saikini de kapsaması gerekmektedir. İlave olarak manevi unsur içerisinde yer alan nefret saikinin, maddi unsuru oluşturan seçimlik hareketlerden bağımsız olarak incelenmesi gerekir. Maddi unsurların ispatlanması, nefret saikinin kanıtlanmasının zorluğuna bağlı olarak, nefret saikinin de oluştuğu karinesine neden olmamalıdır. $\mathrm{Bu}$ şekilde mahkumiyet kararının verilmemesi gerekmektedir.

Nefret saikinin kanıtlanmasına katkı sağlaması amacıyla, saikin belirlenmesinde hangi kriterlerin ölçü olarak kabul edilebileceği bir katalog oluşturulmalıdır. Özellikle, failin suç işleme sebebini, hedefini ve sonucu ortaya koyan somut delillerin neler olduğunun standart olarak katalogda yer alması gerekir.

Bir suç tipinde nefret saikinin suçun unsuru ya da nitelikli hali olarak düzenlenmesi durumunda, saikinin tespit edilmesinin zorluğundan dolayı, kanıtların derecelendirilerek somut olarak ortaya konulması gerekmektedir. Öncelikli olarak failin suçu ikrar edip etmediğinin değerlendirilmesi gerekir. Suçu ikrar etmişse, hayatın olağan akışına göre mevcut ve somut diğer delillerle desteklenen ikrar, suçun sübutu için yeterli kabul edilmektedir. Fail, nefret saikini kabul etmediğinde ise saikin varlığına yönelik tüm şüpheleri ortadan kaldıracak şekilde failin kullandığı söz, ifade ve sembollere bakılması gerekir. Nefret ve ayırımcılık suçunda nefret saikinin nefret söylemi şeklinde değerlendirilebilmesi için ifadenin içeriğinin somutlaştırılması; dışa yansıması gerekmektedir. Fail, fiili gerçekleştirirken ya da gerçekleştirdikten sonra nefret saikini somutlaştıran sözlü veya yazılı beyanlar, nesneler, imajlar veya benzeri diğer hal ve hareketlerde bulunmaktadır. Bu hal ve hareketler, nefret saikinin somut olayda varlığını belirlemede kullanılabilecek kanıt tipini tarif eden tanımlamalar olabilmektedir. Son olarak nefret saikinin kanıtlanmasında suçun işleniş biçimi, failin etkinliği, psikolojik durumu, suç geçmişi, çevresi gibi çeşitli delillere dayanılabilmektedir.

5237 sayılı Kanun'un 122'nci maddesine göre nefret ve ayırımcllık suçu, bir yıldan üç yıla kadar hapis cezası ile cezalandırılmaktadır. 5271 sayılı Ceza Muhakemesi Kanunu’un 272'nci maddesinin 1'inci fikrasına göre, ilk derece mahkemelerinden verilen hükümlere karşı istinaf yoluna başvurulabilmektedir. Bu nedenle nefret ve ayırımcılık suçundan dolayı verilen hükümlere karşı da bölge adliye mahkemesine istinaf başvurusu yapılabilmektedir. 5271 sayılı Kanun'un 286'nc1 maddesinin 2'nci fikrasının g bendine göre on yıl veya daha az hapis cezasını gerektiren suçlardan, ilk derece mahkemesince verilen beraat kararları ile ilgili olarak istinaf başvurusunun esastan reddine dair kararlara karşı temyiz yolu kapalıdır. Nefret ve ayırımcılık suçunun cezasının üst sınırı üç yıl olduğundan, ilk derece mahkemesinden verilen beraat hükmü bölge adliye mahkemesince esastan reddedildiğinde temyize başvurulamamaktadır. 17/10/2019 tarihli 7188 sayılı Kanun değişikliyle 
birlikte temyiz edilemeyecek kararlar kapsamında olsa bile 5271 sayllı Kanun'un 286'ncı maddesinin 3’üncü fikrasında sayılan suçlar nedeniyle verilen bölge adliye mahkemesi ceza dairelerinin kararları temyiz edilebilmektedir. Bu suçlar arasında, 5237 sayılı Kanun'da düzenlenen nitelikli hakaret suçu (md. 125/3), halk arasında korku ve panik yaratmak amacıyla tehdit (md. 213), suç işlemeye tahrik (md. 214), suçu ve suçluyu övme (md 215), halkı kin ve düşmanlığa tahrik veya aşağılama (md 216), kanunlara uymamaya tahrik (md 217) suçları da bulunmaktadır. Sayılan suçlara bakıldı̆̆ında ağırlık, nitelik ve toplumda yaratılan etkisi bakımından nefret ve ayırımclık suçunun da bu suçlar arasında yer almaması eleştirilmesi gereken bir durumdur. Nefret ve ayırımcılık suçunda, suçun ispatı oldukça zor olduğundan, hatalı şekilde beraat kararının verilebilme ihtimali bulunmaktadır. $\mathrm{Bu}$ durumun denetiminin hem istinaf hem de temyiz mahkemesi tarafindan yapılabilmesine imkan sağlanmasi gerekmektedir.

\section{SONUÇ}

Belli bir topluluğa mensup olmasından kaynaklı nefret saikiyle, bir kişi ya da gruba karşı normda sayılan hareketlerin gerçekleştirilmesi halinde nefret ve ayırımcılık suçu oluşmaktadır. Düşünce ve tercihlerin cezalandırılmaması amaciyla kanun koyucunun nefret saikini ceza normuna eklemesi yerinde bir düzenlemedir. Bu nedenle bireylerin sahip olduğu hak ve hürriyetlerden eşit olarak yararlanabilmesi adına ceza hukukunun caydırıcı gücünü kullanmak bir seçenek olduğundan, nefret ve ayırımcılık suçunun düzenlendiği 5237 sayılı Kanun'un 122'nci maddesinde yer alan norm, etkinliğinin olmasından dolayı bir seçenek olarak kullanılabilmektedir.

6529 sayılı Kanun değişikliğiyle birlikte nefret saikinin ceza normuna eklenmesi, 122'nci maddede yer alan suç tipini güçlü kılmasına ve nefret kavramının görünür olmasına katkı sağlamasına rağmen temyiz yolunun kapalı olması, kanun koyucunun kendi iradesiyle çelişmesi olarak değerlendirilebilmektedir. Bu nedenle nefret ve ayırımcılık suçundan dolayı ilk derece mahkemesince verilen beraat kararlarının esastan reddedilmesine dair bölge adliye mahkemesi kararlarına karşı temyiz yolunun açık olması açılması gerekmektedir. 5271 sayılı Kanun'un 286'ncı maddesinin 3'üncü fikrasında sayılan suçlar arasına nefret ve ayırımcılık suçu da eklenmelidir.

Ceza normunda yer alan gruplara yönelik birtakım engellemelerin gerçekleştirilmesi fiilin ayırımcılık suçu olarak kabul edilmesini gerektirmektedir. Nitekim bu durum 6529 sayılı Kanun’un gerekçe kısmında da açıkça yer almaktadır. İlave olarak nefret saikiyle hareket edilmesinden dolayı da 122 'nci maddede sayılan grupların huzursuzluğu, mutsuzluğu, tedirginliği istenmektedir. Bu durum suçun, nefret suçları içerisinde değerlendirilebilmesine de imkan sağlamaktadır.

Nefret suçları, mağdurun ve mensup olduğu grubun sahip olduğu kimliği hedef almaktadır. $\mathrm{Bu}$ nedenle adi suçlara nazaran çok daha fazla zarar verme ihtimali bulunmaktadır. Nefret suçlarında fail, mağdur aracıllğıyla mensup olduğu gruba ötekileștirme amacını taşıyan mesaj vermektedir. Bu durum grubun diğer üyelerinin de savunmasızlık hissi yaşamalarına neden olabilmektedir. Nefret suçlarının, tipe uygun olarak belli bir kategori içerisinde düzenlenmesi kavramın etkili olmasına katkı sağlamaktadır. Bu nedenle adi suçlara göre yapısı ve etkileri farklı olan nefret suçlarının, özel 
bir ceza kanunu ile düzenlenmesi gerekmektedir. Görüşümüze uygun olarak 2021 tarihli İnsan Hakları Eylem Planı’nda nefret suçlarının ayrıca düzenlenmesi taahhüt edilmiş, bu suçlarla mücadele için gerekli tüm tedbirlerin etkin şekilde alınması öngörülmüştür. Özel ceza kanununda öncelikli olarak nefret saikinin tanımı yapılmalıdır. Uluslararası düzenlemelerle uyumlu olacak şekilde 5237 sayılı Türk Ceza Kanunu’nda yer alan hangi suçlarda nefret saikinin mağdura etkisinin daha ağır olduğu belirlenmelidir. Daha sonra ilgili suç tipleri, nefret suçlarının özel olarak düzenlendiği kanuna eklenmelidir. Nefret suçlarının etkin hale getirilmesi adına vakaların tanımlandığı, verilen toplandığı bir uygulama çerçevesinin yaratılması gerekmektedir. Hangi delillerin ne şekilde nefret saikinin kanıtlanmasında dikkate alınması gerektiği yine ilgili özel kanunda yer almalıdır. İlave olarak nefret saikinin somut olayda kantlanabilmesi için gerekli olan göstergelerin belirlenebilmesi adına soruşturma makamlarının eğitime tabi tutulmaları gerekmektedir.

\section{KAYNAKÇA}

AĞIRBAŞLI, Şennur, Sınırlı Ayırımcılık Yasağından Genel Eşitlik İlkesine, Seçkin Yayınevi, Ankara, 2009.

ALEXANDER, Larry, "What Makes Wrongful Discrimination Wrong? Biases, Preferences, Stereotypes, and Proxies", University of Pennsylvania Law Review, 1992, Vol. 141, s. 149-219.

ARTUK, Mehmet Emin/GÖKCEN, Ahmet/ALŞAHİN, Mehmet Emin/ÇAKIR, Kerim, Ceza Hukuku Genel Hükümler, Adalet Yayınevi, Ankara, 2020.

BAYRAKTAR, Köksal, “Nefret ve Ayırımcılık Suçu”, YÜHFD, 2017, Cilt: 13, Sayı: 1, s. 55-81.

BENIER, Kathryn, “The Harms of Hate", International Review of Victimology, 2017, Vol. 23, Iss. 2, s. 179-201. BULUT, İlhan, Nefret Suçları, Adalet Yayınevi, Ankara, 2014.

CANKURT, Ezgi, "Cinsel Yönelime İlişkin Yaşam Tarzına Müdahalenin TCK Bakımından Değerlendirilmesi”, BÜHFD, 2017, Cilt: 3, Sayı: 6, s. 111-139.

CENTEL, Nur/ZAFER, Hamide/ÇAKMUT, Özlem, Türk Ceza Hukukuna Giriş, Beta Yayınevi, İstanbul, 2020.

COESTER, Marc, "Das Konzept der Vorurteilskriminalität", Wissenschaft Demokratie Schriftenreihe des Instituts für Demokratie und Zivilgesellschaft, IDZ, 2018/4, s. 40 - 49.

ÇALIŞKAN, Suat, Hürriyete Karşı Suçlar, Platon Hukuk Yayınevi, İstanbul, 2020.

ÇİÇEK, Gökçe Serim, Türk Ceza Kanununda Nefret ve Ayrımcılık Suçu, Seçkin Yayınevi, Ankara, 2021.

DANCYGIER, Rafaela M./GREEN, Donald P. "Hate Crime”, Prejudice, Stereotyping and Discrimination, (Edited by John Dividio, Miles Hewstone, Peter Glick And Victoria Esses), SAGE, 2011, California, s. 294-311.

DANNER, Allison Marston. "Bias Crimes and Crimes Against Humanity: Culpability in Context”, Buffalo Law Review, 2002, Vol. 6, Iss. 1, s. 389-450.

DEMİRBAŞ, Timur, “Nefret Söylemi ve Nefret Suçları”, Prof. Dr. Şeref ERTAŞ’a Armağan, DEÜHFD, 2017, s. 2693-2701.

DENİ, Buket, Engelli Hakları ve Ayrımcılık Yasağı, Seçkin Yayınevi, Ankara, 2020.

DÖNMEZ, Burcu Demren, “Ayrımcıllk Suçu”, TBBD, 2012, S. 12, s. 10-58.

ERSOY, Uğur, "Nefret ve Ayrımcılık Suçu (TCK m.122)", CHD, 2017, Cilt: 12, Sayı: 34, s. 7-56.

ERSOY, Uğur, “Çağımızın Pandemisi: Nefret Suçları”, TAAD, Yıl: 2018, S: 35, s. 111-174.

HAFIZOĞULLARI, Zeki/ÖZEN, Muharrem, Kişilere Karşı Suçlar, Türk Ceza Hukuku Özel Hükümler, USA Yayınevi, Ankara, 2016. 
HAKERI, Hakan, Ceza Hukuku Genel Hükümler, Adalet Yayınevi, Ankara, 2021.

HARE, Ivan, "Legislating Against Hate-The Legal Response to Bias Crimes", Oxford Journal of Legal Studies, 1997, Vol. 17, Iss. 3, s. 415-439.

İNCEOĞLU, Asuman Aytekin, “Türk Ceza Kanunu’nun 122. Maddesinde Düzenlenen Nefret ve Ayrımcılık Suçunun Nefret Suçu Kavramı Çerçevesinde Değerlendirilmesi”, LHD, 2015, Cilt: 13, Sayı: 150, s. 37-66.

İNCEOĞLU, Asuman Aytekin, Nefret ve Ayırımcılık, Özel Ceza Hukuku Cilt III, Hürriyete, Şerefe, Özel Hayata, Hayatın Gizli Alanına Karşı Suçlar, On İki Levha Yayınevi, İstanbul, 2018.

JACOBS, James B./HENRY, Jessica S. "The Social Construction of a Hate Crime Epidemic", The Journal of Criminal Law \& Criminology, Northwestern University, 1996, Vol. 86. Iss. 2, s. 366-391.

KAÇAN, Gizem, Avrupa İnsan Hakları Mahkemesi ve Türk Mahkemeleri Kararları Işığında Cinsel Yönelim Temelinde Ayrımcılık Yasağı, On İki Levha Yayınevi, İstanbul, 2020.

KARAN, Ulaş, “Türk Hukukunda Ayrımcılık Yasağıve Türk Ceza Kanunu’nun 122. Maddesinin Uygulanabilirliği”, TBBD, 2007, Say1 73, s. 146-173.

KARAN, Ulaş, Uluslararası İnsan Hakları Hukuku ve Anayasa Hukuku Işığında Eşitlik İlkesi ve Ayırımcılık Yasağı, On İki Levha Yayınevi, İstanbul, 2017.

KOCA, Mahmut/ÜZÜLMEZ, İlhan, Türk Ceza Hukuku Genel Hükümler, Seçkin Yayınevi, Ankara, 2020.

KOCASAKAL, Ümit, “5237 Sayılı Türk Ceza Kanunu’nda Nefret ve Ayrımcılık Suçu (TCK m. 122)”, CHD, 2015, Cilt: 10, Sayı: 28, s. 7-40.

LAWRENCE, Frederick M. “The Punishment of Hate: Towards a Normative Theory of Bias-Motivated Crimes”, Michigan Law Review, 1994, Vol. 93, Iss. 2, s. 320-381.

MEMIŞ, Pınar, “Ayırımcılık Suçunun Özürlüler Bakımından Değerlendirilmesi”, GÜHFD, 2009/2, s. 65-78.

MERAN, Necati, Kişilere Karşı Suçlar, Seçkin Yayınevi, Ankara, 2008.

MORSCH, James, "The Problem of Motive in Hate Crimes: The Argument against Presumptions of Racial Motivation", Journal of Criminal Law and Criminology, 1991, Vol. 82, Iss. 3, s. 659-689.

ÖNER, Mehmet Zülfü, “İngiltere Hukukunda Nefret Suçları”, TBBD, 2015, Cilt: 27, Sayı: 116, s. 85-112.

ÖZBEK, Veli Özer/DOĞAN, Koray/BACAKSIZ, Pınar, Türk Ceza Hukuku Özel Hükümler, Seçkin Yayınevi, Ankara, 2020.

ÖZTÜRK, Nurten, Nefret ve Ayrımcılık Suçu, Adalet Yayınevi, Ankara, 2017.

SCHIEDERMAIR, Stephanie, “Avrupa İnsan Hakları Mahkemesi Kararları Işı̆̆ında Nefret Söylemi”, (Çeviren Özdem Özaydın), FHD, 2019, Cilt: 11, Sayı: 115, s. 6-12.

SCHIEMANN, Anja, "Änderungen im Strafgesetzbuch durch das Gesetz zur Bekämpfung des Rechtsextremismus und der Hasskriminalität”, KriPoZ, 2020/5, s. 269-276.

SCOTTING, Troy A. "Hate Crimes and the Need for Stronger Federal Legislation", Akron Law Review, 2001, Vol. 34, Iss. 4, s. 853-892.

SERAFIN, Maja Anna, Hate Crimes: Auf der Suche nach einer adäquaten Reaktion des Strafrechts, Schriftenreihe des Max-Planck-Instituts, Freiburg im Breisgau, 2019.

SINAR, Hasan, “Türk Hukukunda Nefret Suçlarına İlişkin Yasal Düzenleme Çalışmaları”, Prof. Dr. Nur Centel’e Armağan, MÜHFHAD, 2013, C: 19, S: 2, s. 1271-1300.

SOKULLU, Füsun Akıncı, "Hate Crimes”, Annales De La Faculte'de Droit d'Istanbul, 2009, Vol. 58, s. 101-117.

SUllaWAY, Megan, "Psychological Perspectives on Hate Crime Laws", Psychology, Public Policy, and Law, 2004, Vol. 10, Iss. 3, s. 250-292.

ŞAHİNKAYA, Yalçın, Uluslararası İnsan Hakları Hukukunda Nefret Söylemi ve Karşılaştırmalı Nefret Suçları, Adalet Yayınevi, Ankara, 2016. 
ŞEN, Ersan, “Yeni Türk Ceza Kanunu’nun 115. ve 122. maddelerine İlişkin Bir değerlendirme”, İBD, 2005/2, Cilt: 79, s. 359-364.

TANERİ, Gökhan, Hürriyete Karşı Suçlar, Seçkin Yayınevi, Ankara, 2020.

TEKIN, T. “Türkçede Morfofonemik Değişmeler: Dar Ünlü Ø Nöbetleşmesi”, DAD, 1995, 6, s. 103-109.

TÜRAY, Aras, "Nefret Suçları ve Türk Ceza Hukukundaki Güncel Gelişmeler”, CHD, 2014, Cilt: 9, Sayı: 26, s. 77-95.

TÜRAY, Aras, Nefret Söylemi Bağlamında Halkı Kin ve Düşmanlığa Tahrik Suçu, Seçkin Yayınevi, Ankara, 2016.

UYGUN, Oktay, "Nefret İfadesi ve İfade Özgürlügü̈, GÜHFD, 2008, Cilt: 7, Sayı: 1, s. 7-25.

YAŞAR, Osman/GÖKCAN, Hasan Tahsin/ARTUÇ, Mustafa, Yorumlu ve Uygulamalı Türk Ceza Kanunu Cilt III, Adalet Yayınevi, Ankara, 2014.

YURTCAN, Erdener Yargıtay Kararları Işı̆̆ında Hürriyete Karşı Suçlar, İstanbul Barosu Yayınları, İstanbul, 2014. 